\title{
Jacques Ellul's “Anti-Democratic Economy:” Persuading Citizens and Consumers in the Information Society
}

\author{
Artur Matos Alves \\ Universidade Atlântica \& CECL, Lisbon, Portugal, amalves@uatlantica.pt
}

\begin{abstract}
Jacques Ellul's thoughts on the increasingly conspicuous role of persuasion techniques bring to the fore the persuasive and normative effects of new communication techniques at the core of contemporary consumer/citizen culture, as well as the limits of that instrumental stance towards mediated human communication. By drawing insights from authors who shared some of Ellul's concerns, such as Frankfurt School theorists, Vance Packard and Ivan Illich, this paper explores this "normative invasion" of human life by technique as a feature of contemporary information technology politics, specifically in (1) the historical context of normative and material technological colonization, and (2) the intertwining of propaganda and information warfare in the current reshaping of information politics.
\end{abstract}

Keywords: Jacques Ellul, Ivan Illich, Vance Packard, propaganda, consumer, citizen, ICT, cyber-politics, colonization

Acknowledgement: The author received no financial support for the publication of this article. The author wishes to thank the anonymous reviewers and the editor for their comments and suggestions.

"Technique is the boundary of democracy. What technique wins, democracy loses."

- Jacques Ellul, The Technological Society

\section{Introduction}

Jacques Ellul is one of the major names in the philosophy of technology. A member of the first generation of theoreticians to bring technology to the fore of philosophical and sociological debate, he was concerned with the changing conditions of Western society in the wake of industrialization, massification and rationalization. His body of work is currently under renewed interest by the occasion of the centenary of his birth. It sprawls from the analysis of the technological phenomenon, to biographical essays and interviews, to several contributions for dialectical theology. One of Ellul's tenets is the preservation of the individual's moral autonomy vis-à-vis an increasingly hegemonic technical rationalism that delegitimizes political, economic, cultural and spiritual alternatives. Technical rationalism, or technique, is seen as a centripetal force, gradually replacing all alternatives with the efficiency principle and technical expertise based decision-making. Propaganda plays a fundamental role in this system by conditioning the ideological content of symbolic culture, while also affecting the perception and use of alternative discourses within what Ellul calls "the technological society".

This paper will couple the contemporary role of propaganda with the struggle to control communication channels, seeking to assess whether, and to what degree, the current debates about the balance between freedom and security in cyberspace can be viewed as instances of shifts in propaganda and technological myths. I will present an overview of Jacques Ellul's contribution to a critical understanding of the role of technology and propaganda as a starting point for exploring the colonizing and transformative effects of propagandistic elements in information politics. I will also introduce the main elements of 
Ellul's dialectical view, which presents technical phenomena as a closely knit totalizing system interacting with social formation, but gradually marginalizing alternatives, and installing in all areas of human life a set of principles that prioritize maximum efficiency. Ellul's work will be presented and contrasted with other important contributions to the study of propaganda and technology, especially those from critical theory.

In the first section, I will start by exploring Ellul's conception of technique and his view on how propaganda is intertwined with technological discourse, particularly through the exploitation of the perception of threats and risks as opportunities for further technical rationalization. The following section will analyse other contributions to the debate on propaganda and mass culture, including critical media theory, contrasting them with Ellul's work on the subject. Lastly, I will present my views on how Ellul's theory of propaganda systems can contribute to a critical analysis of information politics, particularly regarding the reframing of the role of digital networks and cyber security in the economy, politics and sociability.

\section{Jacques Ellul as a Critic of Modern Heteronomy}

Jacques Ellul's (1912-1994) influence on contemporary philosophy of technology can hardly be overstated. He is widely acknowledged as one of the major contributors to the field, and his extensive body of work presents important challenges to the consequences of modernity. On the occasion of his centenary, his work is being revisited by scholars from different backgrounds in the social sciences, trying to bring into renewed focus the interlocking politics, technology, propaganda, as well as theology, that characterizes this French thinker's writings. ${ }^{1}$ The inspiration Ellul drew from his early readings of Marx was the beginning of a lifelong dialogue - he taught a course on Marx's thought in Bordeaux until the end of his career, besides engaging with other Marxian-influenced thinkers, the most prominent being Cornelius Castoriadis. The emphasis on the moral autonomy of the individual in everyday life and social practice is a salient shared trait, which Ellul maintained in his theological writings, which were influenced by the Swiss theologian Karl Barth.

Widely regarded as a major, but controversial, contributor to a critique of industrial society and the technological phenomenon, Ellul is usually labelled as a conservative, antitechnological thinker. He did indeed grapple with ideological, social and political issues throughout his whole life, refusing what he saw as an uncritical adherence to the generalized technological optimism of the $20^{\text {th }}$ century. He explored technology's ambivalent influence as a material and, more importantly, ideological juggernaut with pervasive effects upon the physical and symbolic worlds. As such, his use of the term technique points to a phenomenon that must not be confused with technology, since it is more akin to Weber's concept of rationalization and its focus on instrumentality. For Ellul, technique's dominion over society is all the more in need of critical analysis as its outputs are unanimously hailed as tools for human progress or emancipation - and its failings presented as human inability in letting technology and experts share their blessings with humanity.

These essential points of Ellul's work make him relevant in a time of finance-driven austerity, when technical expertise and technical imperatives seem to override human wellbeing and social progress, and indeed to go directly against them, intensifying repression, rather than regulation and redistribution, in order to supress the effects of its internal contradictions. Ellul understood that the installation of the mythology of technique needed a wider apparatus of indoctrination and persuasion, in the form of systematic myth-building and strong training and education systems that produce trained personnel amenable to the workings of the technical order. Given the current powerful institutional meshing of these phenomena, revisiting the French thinker - without disregarding recent contributions or the critiques his ideas have received along the years - may contribute to shed light on the entrenchment of technical rationalism in our political regimes, and their capture by the injunctions of the economic, financial and technological realms.

\footnotetext{
One of the important contributions to this on-going debate is the recent volume Jacques Ellul and the Technological Society in the $21^{\text {st }}$ Century (Jerónimo, Garcia, and Mitcham 2013).
} 
In a time when the hegemony of technique was taking root, Ellul's originality resides in disputing the possibility of exclusively technological solutions to social problems, and in emphasising the need to prioritize well-being over the demands of technical rationalism, so as not to exert the extreme costs of technological change on society without compensatory measures that allow for the furthering of human goals (personal fulfilment, family life, cultural and spiritual needs, health). His work departs from a political economy analysis, an endeavour he sees as being concerned with an instrumental reorientation of technique and not as a critique of technique per se. In this regard, he rejects Hayek's famous injunction of economic planning as evil (Ellul 1973a, 178), but rather alerts to, first, the double difficulty of prioritizing and balancing needs and, second, a "planning creep," whereby technical expertise indefinitely extends its internal logic of quantification and efficiency.

In his Preface to Le Système Technicien, Jean-Luc Porquet describes Ellul's view of technique in society as a determinant, ambivalent, self-perpetuating, self-reinforcing, mythcreating, normalizing factor (Porquet 2004, 8). For Ellul, since all aspects of human activity are subject to technical imperatives (at odds with natural or even social factors), it does not remain within the individual's power to alter the direction of social, political or even economic matters, much less to evaluate the criteria implied in the notions of progress: "all these different kinds of 'progress' become feasible only to the degree that men are subjected in advance to the action of technique" (Ellul 1973a, 208, emphasis added). Therefore, he assigns little relevance to the particular political system, whether it is democratic or centralized in nature, or even to the property structure of the means of production. These constitute formal or institutional mediations for a specialized body of knowledge, converted by technical elites into actions directing the economic and social systems towards maximum efficiency, thereby tightening control over State apparatuses and communication channels.

It is in the realm of economic technique that we experience most clearly the great and dramatic process of modern times, in which both chance and natural laws are transformed into decisions of accountants, rules of planning and decrees of the state. (...) Whether the question is one of understanding public opinion, or of stochastics, or of statistics as a whole, the technical starting point is always the human behavior of the majority. From this behavior, technique draws a number of consequences and modes of action, erecting on it the system into which it will necessarily insert itself (Ellul 1973a, 216).

Herein lies the key to understanding what is "antidemocratic" in our economies. The "efficiency principle" of the technological system, by virtue of its universalism, extends beyond the economic sphere. Professionalized politics are also subject to the economy. Even if citizens are permitted to participate through elections and referendums, political systems are increasingly constrained by efficiency laws and rules that set apparently inexorable courses, which provide the universal epistemic paradigm for the administration of human affairs. $^{2}$

Technique has colonized all spheres of activity in a normative, as well as in a material sense (Fischer-Kowalski and Haberl 1997; Krausmann et al. 2008). Therefore, studying contemporary culture critically is to engage with the effects of the extension of this epistemic paradigm into the world of the mind. In The Technological Society, Jacques Ellul highlights the anti-humanistic character of the industrial system, labelling the resulting economic structures as "anti-democratic" (1973a, $215 \mathrm{ff}$.). Ellul's sceptical stance contrasts with 20th century technological politics, which welcomed technological progress as one of the paths towards democratization and emancipation. Opposing his Christian humanism to the technocratic imperatives of the industrial mode of production, Ellul argues that social controls of technical and political processes are, in fact, forms of legitimizing the imposition of industrial production norms upon worker, citizen, and consumer. Moreover, this is an

\footnotetext{
2 Jacques Ellul did not hesitate to consider elections as a legitimizing tool for the technocratic system: as a form of "selection of individuals", or even a limited set of problems and binary answers, election reduces "the problem of participation to its simplest form" (Ellul 1973a, 139), and disavows more direct and diverse forms of participation.
} 
ateleological process. The lack of purpose, of a plan articulating means and ends, indicates that technique evolves through combinatorial, opportunistic tactics of self-adaptation, rather than a global strategy (Ellul 1973a, 97).

$\mathrm{K}$. H. Karim states that "[t]echnique is the overarching feature of contemporary western civilization, according to Ellul; it describes not only the modalities of technology but also the nature of present-day social, political and economic organization" $(2001,116)$. The individual's social role is bestowed on him through several mechanisms. The specific contents of the messages that circulate and "are reproduced" are determined by context and history, but also by the more straightforward logic of necessity. According to Ellul, the particular forms of that logic are a direct result of the structuring of means and ends brought about by technique.

Drawing together technology, culture and society, the industrial "economic imperative" appears as a major guiding force of social attitudes towards technique. Its problematic spread to all areas of social life can also be identified in Illich's notion of "industrial methodology" (1972), which brings the Ellulian concept of technique into a more concrete shape. According to Illich, most major modern institutions - education, health, army, roads or communication systems - are modelled after the factory. Their real aim is to maximize the efficiency of energy use, in order to provide the industrial structure with all the means necessary for its maintenance and expansion - including the adherence of individuals (Illich $1973 ; 1974)$. This technocratic overruling of all other social concerns systematically reduces the individual to the predictable and pliable consumer and/or citizen, aided by the increasing sophistication of political communication techniques, as exposed by early practitioners (Packard 1962). The role of propaganda is, for Ellul, that of a "human technique" techniques for reshaping behaviour and beliefs in order to adapt human beings to the conditions imposed by the continual restructuring of the life world through technique. As such, it is a necessary part of the technical system (1973a, 394; Porquet 2004).

As C. Christians puts it, "[t]he issue is the psychopolitical imaginary universe which humans constitute and reinforce" $(1995,166)$. In this regard, propaganda has an essential role to play in the organization of modern life. Not only does propaganda contribute to maintaining the technical system by ensuring an efficient, continuous flow of information), but it also conditions audiences through the mobilization of symbols and practices, charging them with the hegemonic contents of the technical system. One of the main concerns in Ellul's work is the perceived devaluing of life's material and spiritual dimension by propaganda, skewing them towards the values of technique. This concern is directly tied to his perception of the ascent of systematic propaganda in modern society, as we shall see in the following section.

\section{Propaganda, Democracy and Economy}

The word "propaganda" acquired much of its current sense during the Catholic Counter Reformation movement, with the establishment in 1622, by Pope Gregory XV, of the Sacra Congregatio Propaganda Fide. As a strategy for countering the Reformation movement in Europe, as well as spreading the Catholic faith in the newly accessible parts of the world, it created the basis for systematizing opinion control. "Propaganda" became a term for the organization in charge of that task, it developed to describe the "doctrine itself" and then "to mean the techniques employed to change opinions and spread the doctrine" (Jowett and O'Donnell 2012, 75). Mythology, currency, writing, sculpture, inscription, architecture, poetry, all were deftly used as vehicles for the instrumental shaping of culture by Greek city states, by Hellenistic rulers and Roman emperors, European monarchs, religious leaders and proselytizers, as well as revolutionary pamphleteers. Throughout history, then, "propaganda is an instrument to be used by those who want to secure or retain power just as much as it is by those wanting to displace them," as Philip M. Taylor argues $(2003,5)$.

After an overview of the emergence of modern propaganda and its relation to social mobilization, this section will focus on scholarship of propaganda, especially as a specific modern phenomenon in which the links between politics, economy, culture and the media 
come into focus. The section will briefly summarize some of the most important contributions to the theorization of the phenomenon. I will then present and contrast Ellul's own theory of propaganda.

\subsection{The World Wars and the Rise of Propaganda}

The history of propaganda studies is enmeshed with communication studies. The role of the telegram on the not-so candid newspaper reporting during the Crimean War (1853-56) and the emergence of mass media brought to governments' attention the need to establish controls over the published and the public opinions. By the end of the $19^{\text {th }}$ century, the press had reached the peak of its influence over minds and politics, which presented a strong argument for controlling news items - albeit in varying dosages in peace and in wartime. The advent of $20^{\text {th }}$ century's mass communication technologies (radio, cinema, television) furthered this trend.

Propaganda achieved a very high degree of sophistication during the two world wars, pursuing the same objectives of mobilization, control and demoralization of previous centuries with more powerful technical means. The intensity of propaganda deployment, particularly in Europe after World War I, underlined the urgency of its study as an intentional and systematic form of persuasion, first, in the large-scale forms seen during the conflict (Curnalia 2005, 238), and, later, as a more generalized management methodology for social belief-systems. Ellul dated the rise of modern propaganda to World War I (still "incoherent and temporary") and the Revolution of 1917, when propaganda became "systematic and enduring" (1976a, 104, translated from the French edition).

The World Wars mark important turning points in the history of propaganda. During World War I, previous experiences were expanded and intensified to take advantage of mass communication systems (especially the press and motion pictures). The contenders mobilized and developed advertising industries, created committees and other special initiatives to put together a massive organization with the aims of garnering internal support, influencing neutral positions, and of denigrating, demoralizing and attacking the enemy. ${ }^{3}$ Anti-war positions were systematically condemned and downplayed as part of the war effort on the "home front," something that the British propagandists used to great benefit (Jowett and O'Donnell 2012, 216-228; Ellul 1976a, 104-113). The latter were much more organized and better prepared (through secret bodies such as the Wellington House war propaganda bureau) than their German counterparts, who were mainly focused on military morale and in dismissing enemy propaganda as lies and immoral attacks. Atrocity propaganda was a preeminent feature of this period but, again, the British gained advantage after the sinking of the liner Lusitania in 1915 by a German U-boat, when more than 1.000 civilians (over 100 of which were Americans) perished.

Besides the Lusitania case, the execution of Red Cross nurse Edith Cavell by the German army, as well as other incidents, played an important part in reinforcing pro-war attitudes in American public opinion and demonstrated two aspects of modern mass propaganda: the effectiveness of mass communication messages as psychological weapons (especially demonization tactics and atrocity propaganda) and the value of a professionally organized war propaganda machine. The United States set up its war propaganda efforts around the Committee on Public Information (CPI), directed by the journalist George Creel. One of the priorities was "converting" the internal audience to President Woodrow Wilson's idea of a civilizational "war to end all wars." The CPI's work enlisted advertising companies, the film industry and the press to such an efficient degree that it began to raise concerns about the future of democracy and individual freedom. The role of propaganda had been well established: in the face of total war at a global scale, popular support and morale were to be managed in order to mobilize maximum acquiescence, productivity and efficiency for the war effort.

\footnotetext{
3 The physical disruption of direct communication lines (submarine cables) between Germany and the United States by the British also played a part in World War I, severing important diplomatic and commercial links (Taylor 2003, 177).
} 
During World War II, propaganda had a new instrument at its disposal. Radio had been tested earlier during the interwar period by fascists (such as Mussolini) and democrats (Roosevelt's fireside chats, for example), and it quickly became a mass communication medium. Nazi propaganda, led by Joseph Goebbels, used mass media and Albert Speer's spectacles to strengthen internal support and, later commenters would add, reshape the disposition of the citizens with lasting effects. In fact, Hitler and Goebbels put in place a systematic exploitation of predominant psychological and social conditions created by the defeat in World War I, sustained by a deep understanding of effective communication with the masses: radio, newspapers, leaflets, architecture, rallies; all were used to gain a tight control over domestic conditions. Early victories of Nazi Germany - the Anschluss, the Sudetenland plebiscite and the annexation of Czechoslovakia - were preceded by intense campaigns which made possible the enthusiastic support of German speakers in those areas. British and American propaganda institutions, as had been the case during the Great War, deployed various propaganda strategies to maintain morale, establish a unified "home front," get support abroad, and demoralize the enemy - carefully balancing truth and disinformation, according to the specific purpose. After the Japanese attack on Pearl Harbor in December 1941, the United States rallied behind President Roosevelt and his radiotransmitted voice. Later into the war, the Office of War Information (1943) was established to coordinate domestic propaganda and strengthen the commitment of the American mass communication and entertainment industry. Other contenders in the war - the Soviet Union and Japan - had also developed their own propaganda machines. The former had done so in the wake of the October Revolution, pressed by the need to quickly acquire a strong social basis of support, while the Japanese propaganda apparatus implemented modern techniques after being confronted with hostile propaganda during its invasion of China and the Pacific islands.

In the period after the wars, propaganda's role persisted, and even intensified with the Cold War, drawing on the lessons of the highly effective use of new techniques and media in the first half of the century. Wars raged around the globe, enacting the global drama at local scales (Korea and Vietnam, for instance) and, for the whole world, in yet another new medium - television. Propaganda techniques developed alongside consumerism, morphing into the highly successful promotional sector. The war effort was the crucial purpose of wartime propaganda and psychological warfare; however, peace time advertising was a different form of persuasion and mobilization, also aimed at a permanent conditioning embedded in mass culture, though without propaganda's bad reputation (inherited from State wartime propaganda) as a form of aggressive, warmongering manipulation. Advertising, marketing, and public relations developed tools to allure the population to participate in economic activity as a way of life (both as worker and as a consumer) and to engage in the ideological battle between western capitalism and soviet socialism.

\subsection{Propaganda Studies and Models}

The development of propaganda apparatuses and techniques did not cease during peacetime, and in fact proved expedient for economic, political or ideological purposes beyond armed conflict. As stated above, the sophistication of propaganda apparatuses merited immediate suspicion on the part of the press and scholars in the United Kingdom and the USA, who feared for the independence of the press and individual reasoning under the pressure of emotional and social symbolic manipulation.

Early studies on propaganda were developed by the same experts who had participated in the war effort and developed the apparatuses of modern state propaganda. After the Great War, authors such as Creel, Lasswell, Lippman or Bernays tackled the phenomenon as an integral part of contemporary public communication. In doing so, they launched the basis for communication studies. The first of these four authors retold, in 1920, his experience as head of the Committee on Public Information and acknowledged the role he had played in influencing domestic and foreign public opinion. Stern warnings about the effects of the new dependency on propaganda were also issued by Harold Lasswell, who, in his work 
Propaganda Technique in the World War (1927), considered that the instrumentalization of mass media by propaganda had direct effects on the individuals, creating homogeneous behaviours and beliefs promoted by the messages being spread. Lasswell viewed propaganda as a tool for emotional manipulation that could be deployed to change attitudes and behaviour. The same concern about mass media power over public opinion had been voiced by Walter Lippmann in Public Opinion (1922), as advertising techniques started to develop. While these authors mainly focused on media effects, they shared the view that the coupling of psychological techniques with mass media technologies created a strong force that served the interests of whatever masters happened to wield it, with the potential to make political communication more efficient in mass democracy.

Edward Bernays extolled propaganda as a necessity of modern society: it is the means for the elite - business leaders, politicians, and the state - to keep mass society under control. The context and methods, the quality and objects of propaganda may change, but not its function. The closing paragraph of his book Propaganda reads: "[i]ntelligent men must realize that propaganda is the modern instrument by which they can fight for productive ends and help to bring order out of chaos" (Bernays 1928, 159). This instrumental view of propaganda and the inevitability of its effects led to a comprehensive analysis of political economy factors; instead, it focused on the behavioural effectiveness of massive campaigns and the potentials of new (quasi-scientific) techniques.

One of the first models of propaganda addressed the deepening links between economy, culture, politics and advertising by looking into the linguistic and rhetorical properties of the messages. It was developed in the interwar period by the scholars of the Institute for Propaganda Analysis (IPA) of Columbia University and published in "How to Detect Propaganda" (1937) as part of a series of materials for raising awareness of propaganda techniques and educating for its detection in national and foreign materials. It detailed seven distinguishing aspects of the content of propaganda messages that could be used as the basis for simple analytical work. These were, in fact, common language "tricks" to which propagandists resorted and could be detected by anyone in a given text: "name-calling," "generality," "transfer," "testimonial," "plain folks," "card stacking," and "band wagon" (Jowett and O'Donnell 2012, 237). ${ }^{4}$ This approach retained the idea that emotional manipulation was the core of propaganda. This model did not take into account crucial aspects of institutionalized propaganda, such as production or reception, but had the definite advantage of the simplicity of its approach.

Yet, the increasing sophistication of propaganda systems was very hard to capture in such simple models. The IPA did not survive the onset of World War II, finding it impossible to pursue its program of content analysis in the face of the mobilization of public opinion for the war. The history of critical theory is also linked to the turmoil of the war years: the founding members of this intellectual movement were forced into exile in the United States as the Institute for Social Research in Frankfurt came under attack after 1933. Adorno, Horkheimer and Marcuse were among the intellectuals engaged in the critical assessment of contemporary culture and its transformation through the emergence of mass media.

Critical theorists did not hold mass culture in high regard. Perhaps with the exception of Walter Benjamin, they maintained a sceptic position about the possibility of critical emancipation in the context of mass culture, or rather "the culture industry." In Dialectic of Enlightenment, Horkheimer and Adorno analysed the culture industry as a generator of false social consensus and one of the sources of the hegemony of instrumental logic. The consequences of its workings were dire: alienation, loss of critical reasoning, atrophy of

\footnotetext{
4 "Name calling" is the process by which an idea or person is given a bad name in order to discredit it without rational examination. "Glittering generality" refers to the association of an idea to a second idea or word in order to assign an intended character - positive or negative. "Transfer" consists in the positive or negative association of respect commanded by something to another idea. "Testimonial" is the process by which a loved or hated person conveys the message that an idea is good or bad. "Plain folks" is a method of identification between a speaker and the audience by stating that the former is a common person. "Card stacking" consists in selecting facts, examples or other statements in order to convey the intended message. "Bandwagon" refers to a form of persuasion based on the argument of generalized social acceptance.
} 
imagination and spontaneity, mediocrity, maintenance of the status quo and the promotion of novelty for its own sake. The culture industry and mass media linked social uniformity (conformity) to economic necessity: "freedom to choose and ideology, which always reflects economic coercion, everywhere proves to be freedom to be the same" (Horkheimer and Adorno 2002, 135-136). This was, in short, an expression of the economic and political power of the elites under the guise of choice and technological reason.

Propaganda was an integral part of this system, incessantly conveying messages to be enjoyed uncritically as mass entertainment or amusement. Messages were to be converted into beliefs and behaviours, encouraging and reinforcing adaptation to this system of technical instrumentality. Their existence was essential, because to be outside the margins of this quantified, categorized society is to be unable to participate in it. Advertising lost its social informative role to "strengthen the bond which shackles consumers to the big combines" (Horkheimer and Adorno 2002, 131), a pervasive phenomenon that feeds back into the monopolistic logic of large organizations. Perversely, the "consumers of cultural commodities" are aware of the manipulative or false character of culture industry goods, but they do not seem to have a choice beyond integration with "compulsive imitation" (Horkheimer and Adorno 2002, 136). This false consciousness protected this cryptototalitarian system of its dialectical counterpart, which was to be supplied by critical theory itself.

Critical theorists also shared a critical view of contemporary technology, and both Horkheimer and Marcuse linked it to forms of domination that monopolized the positive potential of modern technology and closed off its affordances except insofar as it might be profitable or advantageous to partially distribute them. "[T]he basis on which technology is gaining power over society is the power of those whose economic position in society is strongest. Technical rationality today is the rationality of domination," which replaces objective reason with subjective interests (Horkheimer and Adorno 2002, 96). In this way, it is diverted into instrumental reason: "[h]aving given up autonomy, reason has become an instrument. [...] completely harnessed to the social process. Its operational value, its role in the domination of men and nature, has been made the sole criterion" (Horkheimer 2004, 1415). In order to reclaim technology, it would have to be reinstated into a rational and positive realm of progress.

Marcuse in his One-Dimensional Man (1964) demonstrates a concern similar to Jacques Ellul's regarding the phenomenon of technical thinking and its effects on modern life, trying to unravel the "compulsive" character of integration in the mass society. The famous indictment of capitalist socio-technological systems as opposed to democratic freedom echoed the words of Ellul in this article's epigraph: advanced industrialism has installed a self-sustaining ideology of instrumental rationality that runs contrary to democratic freedom. Marcuse criticized the "exploitative features" of centralized technical direction, especially in its negative effects on self-determination, meaning its potential for the reduction of the exercise of autonomous reason in the confrontation with the hegemony of technical rationality (Marcuse 1964, 253). However, even as he warned against technological fetishism and false needs that generate a false freedom in a passive audience, Marcuse exalted the emancipatory potential of technological rationality to eliminate scarcity and the struggle between man and nature, as well as to provide spiritual and aesthetic fulfilment, that is, to answer true human needs. Therefore, he did not entirely despair of modern technology, highlighting its potential for the pacification of existence, or "pacified existence" (Marcuse 1964, 235).

Kellner (1984, 264-265) argues that, for Marcuse "the problem in advanced capitalist society is not that people are enslaved by technology, but that it functions in many instances as an instrument of class domination", which contradicts the emancipatory deployment of technology. Both Horkheimer and Marcuse stressed that the specific organization of productive forces in capitalism restricted most of the social benefits of modern, industrial "technological rationality" (characterized by scientific and technological progress, efficiency and mechanization) by supplanting it with "capitalist rationality" (predicated upon private property and the maximization of profitability) and gradually restraining self-determination 
and freedom (Marcuse 2004, 44-45). Unlike Ellul, Marcuse did not entirely oppose industrial technology, but its implementation under capitalism. In fact, he looked past contemporary industrialist exploitation and the struggle for the conditions of existence, towards a communist ideal of human fulfilment, that is, true freedom. Changing the political character of industrialism would be an integral part of that transition. That would entail replacing instrumental reason and driving out the false needs that perpetuate the economic and social structure of domination of capitalistic industrialism. In this sense, the author assigned technology a most important role in bringing about the end of history as a struggle, through emancipation from want and suffering by way of a democratic, humanistic implementation and governance.

An important part of Marcuse's work on propaganda focused precisely on how nationalsocialism mastered it for the purposes of domination and indoctrination. Marcuse specified, in State and Individual under National Socialism, that it "tends toward direct and immediate self-government by the prevailing social groups over the rest of the population. And it manipulates the masses by unleashing the most brutal and selfish instincts of the individual" (Marcuse 2004, 70). In The New German Mentality, the author highlighted the effectiveness of propaganda in the shaping and mobilization of the minds of German people precisely in order to serve the expansionist, predatory industrial capitalism of the dominant groups and businesses.

For Marcuse, who studied German propaganda during the war, Hitler and Goebbels "changed the thought and behaviour pattern of the German people" $(2004,141)$. Marcuse posited two layers in this new mentality: a pragmatic and mythological layer. The first included the efficiency principle, mechanization and rationalization, while the second fostered paganism, racism and vitalism (Marcuse 2004, 141-142). This coupling of technical rationality with a highly regimented political and social life resulted in a complete domination of the social sphere and strangled any progressive alternatives. It marked a new stage in the submission of the work force and all creative energies to industrial efficiency and the dictates of the totalitarian state: "[i]ntegral politicalization is the National Socialist concomitant of the transition to a planned economy within the established social framework; integral debunking, cynical matter-of-factness and the shifting of traditional taboos are the German features of technological rationality, and neo-paganism serves to crush the psychological and emotional resistance to ruthless imperialist conquest" (Marcuse 2004, 146).

Marcuse concluded that efforts to reverse that change risked faced great difficulties, given how ingrained the new ideology had become on the collective psyche by way of regimentation, fear-mongering and linguistic manipulation. Accordingly, his analysis stressed the enduring social, cultural and ideological effects of propaganda, in the context of a project for a radical change of mentality. According to Marcuse, the success of Nazi propaganda can be attributed to the effective use of new media (radio, in particular) but also, more importantly, to an effort to completely reshape beliefs and forms of thinking. This prompted him to outline new methods and a new language to counter the effects of a decade of Nazi domination - a language of facts, recollection and re-education (Marcuse 2004, 165). Allied counter-propaganda would need to address the specific changes undertaken by German mentality: it had to be pragmatic (about facts, power and efficiency, and not ideology) and objective-oriented (the defeat of Nazism, and not of Germany). At the same time, Marcuse warned that it would be essential to show the links between Nazi imperialism and Nazi "big business" in order to demonstrate that the war reinforced their vested interests (Marcuse 2004, 177). Counter-propaganda would also need to bring out and foster redeeming forces, symbols and ideas not appropriated, discarded or destroyed by the totalitarian grip.

Herbert Marcuse demonstrated the power of propaganda in the regimentation of political discourse and thought, a drive that produced irrationality out of a highly rationalized organization aimed at domination. Insofar as it maintains its hold over the symbolic, propaganda cannot be deconstructed except by way of another instrumentalization of communication able to reinstall autonomy. In Habermas we find a refined notion of the value of the public exercise of reason in the public sphere, where discourse, rationality, and the specific conditions for social and political communication come into focus as the basis for 
freedom and equality in modern societies (Habermas 1962). Habermas shares with Ellul an insistence in the autonomy of individual conscience in its relation with morality. For Habermas, the normative colonization of the "public sphere," first by the early mass media, and then by the professional cohorts of propagandists and promotional experts, presented a serious threat - or, at least, a "strange element" - to its independence from political institutions (Silva 2002, 59). Media hegemony and the corresponding commodification and massification created serious limits to autonomous political reasoning, especially since internal democracy and independence of the media receded into secondary matters. "Scientization" conditioned public communication, transforming most of it into a commercial venture more concerned with its own performance than with its social role (Habermas 1989a).

Herman and Chomsky's propaganda model $(\mathrm{HC})$, laid out in Manufacturing Consent (1988), remains a powerful framework understanding how changes in the public sphere reflect the political economy of capitalist societies. By focusing on the organization and structure of the media - particularly their sources of funding - and not on their effects or the contents of media products, this model proposes a systemic view of propaganda as it develops in a specific media environment. The model aims to present a better comprehension of the workings of the media system in capitalist societies, reflecting the persistence of inequalities of influence, capital and power that affect the general outlook of public communication. The model presents five "filters" that determine how commercial media "filter out the news fit to print, marginalize dissent, and allow the government and private interests to get their messages across to the public" (Herman and Chomsky 2002, 2), namely: (1) size or ownership of the dominant mass media firms; (2) sources of income, particularly advertising; (3) sources of information used by the media, particularly regarding their reliance on "information provided by government, business, and 'experts' funded and approved" by them (Herman and Chomsky 2002, 2); (4) "flak", or responses to media content that feed back into its content as self-censorship; and (5) originally "anticommunism", following the Cold War logic, replaced with "faith in the market" (Herman 1996; 2000) or "the provision of an Enemy or the Face of Evil" (Herman, Chomsky, and Mullen 2009, 14). These five filters produce a consistent bias which is favourable to institutional allies and to corporate interests.

Since the original publication of Manufacturing Consent, this model has been updated, tested and extended in order to reply to criticism and address historical changes (Sparks 2007; Klaehn 2009; Mullen and Klaehn 2010). For the authors, "the changes in politics and communication over the past dozen years have tended on balance to enhance the applicability of the propaganda model" (Herman and Chomsky 2002, xvii). The trends of media concentration, growth of multinational conglomerates and globalization have altered the global communication landscape. The global media system is more similar than ever to the American model that served as the basis for the $\mathrm{HC}$ model and its original case studies. Even the hopes for the organization of the proletarian class that produces media content, especially journalists (Sparks 2007, 83), seem to be misplaced, as companies answer the haemorrhage of advertising income with layoffs and de-professionalization. It is not without reason that Gerald Sussman evaluates the current outlook as a failure of the political process to limit the "corporate takeover of civil society and the mediation of social and personal interaction by advertising" $(2011,7) .{ }^{5}$ In fact, the political sphere itself seems to have been colonized by multinational corporate interests to a very high degree. If, as Herman explains, the power of propaganda stems from the coordination of an elite, then the global reach of that "elite consensus" of the group of owners of private media translates into generalized constraints to public debate, even as the global reach of the digital media seemed to promise

\footnotetext{
${ }^{5}$ Gerald Sussman links the "growing commodification of public and professional life" $(2011,16)$ to a twofold operation of public communication. On the one hand, propaganda as "highly organized doctrinal texts communicated throughout the sound and visual media in the service of state and corporate interests (and aspiring elite)" On the other hand, promotion, that is, "the regular employment of advertising, marketing, direct marketing, public relations, and other selling initiatives on behalf of both elites and non-elites by those trained as active promotional and self-promotional agents" (Sussman 2011, 1).
} 
the exact opposite (2000, 104; Sparks 2007, 72-73; Herman, Chomsky, and Mullen 2009, 12).

The $\mathrm{H} / \mathrm{C}$ model, by combining institutional analysis, political economy, elite theory and social critical theory, offers a robust tool to understand, both at the local and global levels, the flow of influence, power and capital through the media system. The $\mathrm{HC} /$ propaganda model places a great deal more emphasis on the power of capitalist elites and media corporations than on the audience. In the light of the history of propaganda, that is justified, but must be tempered with an additional concern with changing contexts and changing needs - even if those needs are false and artificial, as Marcuse remarked.

Another model for the analysis of propaganda was presented by Jowett and O'Donnell (1986). It focused less on the workings of mass media systems, in that it contained several dimensions, modelled at a higher level than the $\mathrm{HC}$ theory. It presented "propagandistic communication as a process within a social system" (Jowett and O'Donnell 2012, 359). The model's axis was institutional, although it included, as parts of the process of message flow, the social historical context, a "cultural rim" (government, ideology, events, myths, social practices, economy), the institution that initiates the message, propaganda agents who "send out ideology" for an institution through the media, media methods (technologies and techniques), the social network (opinion leaders, gatekeepers) and, finally, the public, either in general or as a specific segment of the audience (Jowett and O'Donnell 2012, 359-366).

In this model, propaganda and culture are affected by each other in a lasting manner, but there is a strong dynamic quality (or meta-stability) to be found in the combination of the elements. This model places the most emphasis on the social-historical background. The operation of propaganda is a complex process that reflects the particular state of a dynamic system and, therefore, it is clear that major changes in media methods (such as new media or even new regulation) will ripple across the other elements. As the authors demonstrated in the case studies presented in the latest edition of Propaganda and Persuasion (including the analysis of tobacco and pharmaceutical companies propaganda campaigns, and the preparation of the invasion of Iraq in 2003), as the main elements are addressed a clear picture of the particular workings of propaganda campaigns begins to appear - a complex interweaving of symbolic, ideological and material aspects wielded by all participating actors, to varying degrees of efficiency (Jowett and O'Donnell 2012, 289-306). According to this view, all components need to be favourably mobilized in order for propaganda to succeed.

Later, post-modernist critiques of propaganda, such as Baudrillard's, address it in all its forms as defining public communication practices in contemporary societies (Baudrillard 1978; 1996; Merrin 2008). At the same time, they took a critical stance regarding the political economy of industrial (and post-industrial) societies, continuing the work of the Frankfurt School and later theorists (most importantly, the influential work of Herman and Chomsky cited above). Baudrillard considered that the pervasiveness of mass communication conceals propaganda's effectiveness while taking advantage of it: persuaders do not create from scratch. They explore society's ideological constructs from a centralized (and only superficially pluralistic) power structure, even if in the process they become devoid of referential value (Baudrillard 1988, 141).

A common perspective arises from $20^{\text {th }}$ century propaganda studies, which is also present in Jacques Ellul's work: persuasion is nearly always opaque. It is widespread and irrespective of specific institutional settings or political systems, though it requires a definite effort to adapt it to the existing conditions. Below I will detail Ellul's approach to propaganda as interplay between the requirements of modern existence and the mobilization of individuals in mass society.

\subsection{Propaganda in Ellul's Theory}

Already powerful professional tools of economic and political planning by the time Ellul first published The Technological Society, the "techniques of manipulation" steadily gained prominence throughout the 20th century and the first decade of the $21^{\text {st }}$. The early scholarly efforts just described gave way to more solid studies based on critical approaches, 
fundamentally changing the understanding of communication in our society. Ellul turned his attention to propaganda at a time when its systematization was advancing rapidly, stressing its changing character according to specific social and political contexts (Ellul 1962; 1976a; 2010). Today, as information security and digital communication emerge as major global concerns (Taylor 2003; Macdonald 2006), public and political discourse is colonised by the continuing conversion of technological norms into law facilitated by a new form of "disaster propaganda" that focuses on the risks of digital communication networks. Before examining this phenomenon in closer detail, I will explore Jacques Ellul's contribution to the study of propaganda and its character as a social phenomenon, in order to put forward a comprehensive systemic view of its practical effects on modern society.

Propaganda is not just about lies and wrongful persuasion. According to Kenneth Payne, it "is a conscious act of construction, bringing the discipline within the ambit of psychology and anthropology. The successful propagandist has grounded their message in the narrative elements most likely to resonate with the target groups" $(2009,110)$. Propaganda influences opinions, attitudes and applies continuous reinforcement by saturating public communication with calibrated messages, in order to establish their relevance through the differentials that characterise specific symbolic cultures. The techniques of manipulation engage with and adapt to their target's culture with the purpose of focusing and orienting large numbers of people towards economic, political, and military goals.

Ellul's analysis of propaganda was thorough, and although it may be outdated in some respects, in others, such as the specific dialectical aspects of institutional propaganda and social communication, he went beyond other theorists. His characterization comprised several dimensions which together shed some light on the basis for its effectiveness. Among the external characteristics, Ellul lists as targets both "the individual and the masses" (1973b, 6 ). Here, the mass consists of a body of individuals with similar characteristics or profiles (which is simultaneously a sociological condition for the existence of propaganda). Propaganda therefore takes advantage of mass communication (another sociological precondition) to reach segmented audiences - individuals who are alone together.

Since propaganda must employ all available means and exploit all available resources (language, emotion, reason, images, myth, and objective conditions such as a certain standard of living, average culture and information, or ideology), as well as achieve efficiency in the suitability of means and ends, it must be "total" and "well-orchestrated" (Ellul 1973b, 12-13). Thus, propaganda reconstructs reality from within, both aesthetically (as Adorno and Horkheimer feared) and historically, through a mesh of truth, tradition, myth, misinformation, rumour, lies or opinion (the formation of a homogenous public opinion in a mass society is an essential feature of the propaganda system for Ellul). ${ }^{6}$ For that to happen, propaganda also needs to be continuous, so it is not perceived as such. It overcomes resistance by overwhelming the individual to the point that it becomes an uncontested part of his world which is why electoral propaganda is so much more noticeable than the promotional materials that saturate our everyday life. Another external feature is its institutional character: propaganda acts through organizations and propagandists (professionals) that ensure continuity and totality at different social levels. Propaganda is orthopraxie. Its objective is not to "change ideas, but to provoke an action. It is also not to make one change his allegiance to a given doctrine, but to irrationally engage him in an active process" (Ellul 1962, 36-37, emphasis added). ${ }^{7}$ The individual undertakes the action predicted by the propagandist, in an efficient and economical fashion. His intellectual adherence is unnecessary (although myth is useful), since all considerations are embedded by the propagandist in the message conveyed to his object. The action is defined a priori and the correct technique is

\footnotetext{
${ }^{6}$ It should be noted that Ellul did not think that anyone could be free from the effects of propaganda. Repetition and saturation would, in the end, condition all members of an audience by providing them with consistently false or incomplete information. For example, as a Marxist sympathiser, he was deeply affected by Krushchev's revelations about the Stalinist period. For Ellul, as later for Herman and Chomsky, being informed is not the same as having complete knowledge, and an elitist attitude towards mass communication is an ineffective defence against false consciousness.

7 Translated from the French edition.
} 
implemented, materializing a functional separation between thought and action - behavioural "conditioning" - in contemporary society (Ellul 1962, 39). As Bernays had previously suggested, thought would be an exclusive of specialized elites, and action would be all that remained for the masses, given the sophistication of persuasive techniques and the efficiency of mass communication.

The internal characteristics of propaganda included the "knowledge of the psychological terrain" (Ellul 1973b, 33), with the purpose of making use of the psychological conditions of the target audience (in individuals and in society as a whole) to the extent needed to prompt the desired attitude in a given time frame (while the conditions are favourable for the desired outcome). For Ellul, the propagandist has to establish a form of creative continuity in order to utilize current opinion and beliefs. To contradict them would be to elicit an attitudinal negation that is entirely contrary to the tenets of propaganda. Above all, it is necessary to exploit, as resources, the current state of the audience, employing techniques such as those detailed by the IPA to maintain a certain degree of narrative coherence. An example of this today is the narrative of progress and growth through innovation (which I will address below). This does not require social homogeneity, but rather the careful consideration of the idiosyncratic character of public opinion and social sentiment in a given context. This ideological outlook presents itself as an objective condition and pretext for propaganda, supplying themes, contents and arguments (Ellul 1973b, 117). The historical condition of human existence is another dynamic element - not only is it impossible to use the same strategies across the globe, it is also necessary to adapt to the changing conditions in a given society. The messages need to be "calibrated" (never blatantly false, but carefully controlling its conditions of interpretation and accuracy) according to the events and the public's reaction. The individual retains some autonomy, but is clearly powerless in the face of circumstances (natural catastrophes, war, or political turmoil): the more interest the historical situation elicits, the more the individual is exposed to it.

Ellul distinguishes several categories of propaganda. The first two are political and sociological propaganda. The first consists in "techniques of influence employed by a government a party, an administration, a pressure group, with a view to changing the behavior of the public" $(1973 \mathrm{~b}, 62)$. In turn, sociological propaganda is defined as "the penetration of an ideology by means of its sociological context" (Ellul 1973b, 63), that is, the conditioning of society through its circumstances, especially material conditions (economy, political system) generating a more diffuse set of messages. Sociological propaganda also promotes changes of habits, even though it comes from custom, social judgement, selfcensorship and the micro disciplinary apparatus of everyday life. As G. Sussman argues, "ideology is constructed through interplay between base and superstructure, between culture, including its residues of earlier cultural epochs, and the reflexive practices of cultural, social, and political economic institutions" $(2012,478)$. Furthermore, to the extent that mass media replicate and amplify general sentiment, sociological propaganda is propagated through the same channels, reinforcing itself and acquiring the more deliberate character of an ideology. In the case of "the American way of life," for example, its concrete trappings and well-defined ideology makes it an ideal tool to extend influence beyond national borders through positive representations in the media.

A second distinction opposes agitation propaganda and integration propagation. Agitation propaganda seeks to overcome a given situation, and is led by the opposition in order to overthrow its enemies - usually in a revolutionary situation. Integration propaganda, on the other hand, has an organic role: it aims at "rationalizing an existing situation, [...] transforming unconscious actions of members of a society into consciously desired activity that is visible, laudable, and justified [...] stabilizing the social body, at unifying and reinforcing it" (Ellul 1973b, 75). It is precisely because of human resistance to the modern way of life that technological societies require propaganda - it establishes praxis, preferably weeding out destabilizing, revolutionary or even excessively conservative positions. Following Bernays, Ellul concludes that society needs propaganda to fulfil a definite role: integration of the individual and the masses into the technological system. That means "naturalizing" modern life for everyone - a mandatory form of integration in order to survive 
and thrive as a human being. Propaganda "provides the social glue that modernity otherwise tends to dissolve, but [Ellul] points out as well that propaganda also contributes to the alienation it exploits" (Wollaeger 2008, xiii). In a word, it fosters adjustment. Polemically, Ellul added: "the more comfortable, cultivated, and informed the milieu to which it is addressed, the better it works. Intellectuals are more sensitive than peasants to integration propaganda. In fact, they share the stereotypes of a society even when they are political opponents of the society" $(1973 b, 76)$. This statement places Ellul squarely at odds with the Frankfurt school by denying the intellectual any critical vantage point over the prejudices of its own society and subjecting it to the same affectional dispositions of everyone else. There is an important role even for a dissenting intellectual: voicing disagreement in our societies, while critically important as duty and right, seldom does little more than legitimizing the majority opinion by highlighting its magnanimous tolerance for dissent, since ideological critique is scrupulously kept at bay, or put back to work as a productive myth of pluralism (Wollaeger 2008, 12).

A third distinction opposed vertical and horizontal propaganda. The first corresponds to the classic understanding of propaganda as a top-down phenomenon directed at the masses. Horizontal propaganda can be defined as form of participatory propaganda, directed by members of a given group to foster the adherence from other members. The last distinction is made between rational and irrational propaganda. Rational propaganda rests on the communication of quantifiable and verifiable data (such as advertising the technical details of a machine) to persuade the audience. Irrational propaganda, on the other hand, relies on the manipulation of human emotion - something that, as Ellul notes, tends to be more noticeable. It therefore gives way to content that adheres more strictly to the trappings of rationality and factuality that, in turn, generate a more effective general impression after the finer details fade from memory (Ellul 1973b, 86).

Since propaganda is a necessity in the technological society, both for the state and the individual, it would be wrong to see the public as "victim and prey." Ellul considered that might be true for early forms of advertising, tasked with getting information across to consumers (1973b, 119). However, propaganda became an instrument for fulfilling needs of the state and the individual because it responds to sociological needs within the group: masses are required to participate in the political process, and the state needs to engage with that participation, constantly gauging public opinion and attitudes. Which is not to say that this process facilitates democratic expression; rather, it allows the state to pursue its functions by influencing the shaping of public opinion. Steering public opinion "manufacturing consent," in the words of Lippmann - is a core function in mass democracies. Propaganda is, then, a tool for state legitimation, for compliance with its form and decision at all times. Since it requires citizens to be mobilized to execute what are, fundamentally, technical decisions with little participation or public deliberation, the state creates, through propaganda, a permeating sense of informed consent.

On the other hand, the individual needs propaganda to help him face his condition (Ellul 1973b, 138). This condition is characterized by an outward defence of one's own autonomy and independence, while actually an unconscious need is at work. Citizens cannot bear feeling powerless, but neither would they wish to make critical decisions: the modern individual needs to have a certain degree of information in order to function and participate. Information is often complex, hard to get or just too much for individuals to formulate autonomous judgements in a rapidly changing environment. For Curnalia, "propaganda offers the justifications individuals need... a sense of righteousness in complying... [and] crystallizes individuals' opinions so that they reject alternative perspectives and ideas (2005, 238). Jay Black adds that even a "fully functioning democratic society" cannot presume to work without propaganda, despite requiring pluralism, along with a critical and concerned media audience $(2001,135)$.

Hence, "[p]ropaganda succeeds only to the extent to which man is prepared to receive it, and where there is a sort of previous connivance between propagandist and propagandized" (Ellul 1975, 190 n. 9). By the effect of what is termed "the individual's laziness," messages need to include ready-made value judgements and coarse simplifications that allay the individual's despair at having little control or supervision over decisions made by political and 
technical elites (Ellul 1973b, 140). Propaganda hence helps to convey ideology and accelerates the processing of social information. As Adorno, Horkheimer and Marcuse concluded, this creates the illusion of freedom by limiting the available positions (and actions) within a given social system. In much the same way, entertainment masks the drudgery of routine: if "man is not automatically adjusted to the living conditions imposed on him by modem society" (Ellul 1973b, 143), then it is the task of news media and the culture industry to satisfy a passivity that may yet pass as informed consent - mainly by providing sanctioned escape paths in an increasingly routinized existence.

Ellul saw propaganda as a pervasive phenomenon of the modern world, regardless of political regimes. As a technique of manipulation, it aims to build conditions of acceptance of reality, as well as to lay the principles of its further development (Ellul 1962, 174-177). In its narrow sense, propaganda "is defined by its institutional character. What defines it is a combination of techniques of psychological influence with the techniques of action-oriented organization and training" (Ellul 1962, 9). ${ }^{8}$ It can draw on pre-existing symbolic resources to structure its informational flows for efficient persuasion; traditional wisdom, trends and fashions, mass media and erudition are used as grounds for psychological action and warfare, as well as re-education and brainwashing (ibidem).

Since the French philosopher was convinced that the colonizing character of modern technique percolated the behaviour of human beings, it is clear that propaganda plays an important part in Ellul's contrasting of economy and democracy. Propaganda needs to assert itself seamlessly in the cognitive lives of the public so that it can be effective. Its function is directly linked to the "tendencies of the technological society" $(1962,179)$, supplying selfjustification to the individual and the group in order to assure the organization of the political and economic world. As a predominantly symbolic and cultural phenomenon occurring through conscious and unconscious processes, propaganda replicates itself regardless of the specific means of dissemination. In behavioural terms, its effects can be seen as forms of normative and behavioural conditioning: psychological crystallization, alienation, dissociation, and dependency. The influence on psychic life is, for Ellul, an extension of the drive for efficiency, but now aimed at enacting activity changes. A non-instrumentalist form of propaganda is difficult to envision: insofar as it fulfils a role in the communication system of modern societies, propaganda is not entirely replaceable by traditional forms of information exchange and opinion formation, such as everyday conversation and assemblies, which lack mass reach. But nor must propaganda necessarily entail the reduction of communication to the instrumentalization of individual or social action.

Taking industrial methodologies as model, Ellul's technique gradually becomes the most powerful force in society. Not as a specific disposition of contradictory social forces evolving throughout history, as Marx believed, but as a particular state or combination of technology and culture that achieved dominance as recently as the $20^{\text {th }}$ century. Ellul saw technique as forcing the adaptation of society to its demands. In order to reach that goal, it sets forth an apparatus of strong "agents of adaptation" - among which we find propaganda and entertainment - that have become an integral part of a thoroughly organized society (Ellul 2004, $322 \mathrm{ff}$.). The dependency on mediation is a critical factor and, as Langdon Winner concludes, the way out at the individual level is to restore "the validity of a person's direct experience .... of inquiries and discussions that bring to focus the most basic questions about our shared existence and common commitments" (Winner 2013, 112).

It is propaganda's permanent masking that makes it hard to detect and analyse, especially in order to make a practical (not conceptual) distinction vis-a-vis information. The modern "psychopolitical universe" (Christians 1995) is permeated with messages that circle back and forth, redrawing the boundaries of the good life and defining conditions for existence and subsistence in the contemporary world. As Habermas, Ellul was concerned with the rationalization of choice and technocratic domination shrinking the territory of political

\footnotetext{
${ }^{8}$ Translated from the French edition.
} 
deliberation. ${ }^{9}$ In other words, if we follow Ellul's reasoning on the mutually dependant economic and political systems, it is almost inevitable to regard public discourse as a selfreinforcing feedback mechanism whose power grows through symbolic and technological means.

\section{The Construction of the Myths of Technique}

In Ellul's framework, democracy, information, and technology are morally independent both as concepts and realities. Even though they often appear optimistically tied together, their value has been transferred to their representations, as signs that remain in place as means (for propaganda) after their loss of meaning on the path to current society models. By displacing knowledge and information to the realm of simulation and artifice, propagandistic practices perpetuate the myth of the necessary link between democracy, economic growth, and information.

Baudrillard's later critique points to the same hollow space we have encountered in Ellul's thought: if the prevalence of information technology and consumer economics erodes the commonly posited connection between self and world, the theoretical re-establishment of stable categories is an extremely difficult task. ${ }^{10}$ This occurs because individual identity formation (profession, leisure, education, status) that translates into consumption (material or immaterial) feeds into the technical realm of economics, whereas a particularly well-informed and participating citizen is not relevant, either politically or economically. All that matters, in this sense, is organizing the symbolic sphere to ensure the decoding of the aspirations of the individual into the measurable material practices of the consumer-as-body that signal economic growth: exactly the kind of methodology that suits the technical system.

In order to accomplish that, the symbolic realm needs to undergo a permanent refashioning: consumption as economic activity is tied to the creation and manipulation of meaning affixed to the affective world of mass consumption. The flow of consumption is ensured not only by responding to the needs, but also by allowing a great deal of plasticity of identity through the creation of desire - the saturation of the symbolic sphere with constantly changing and contradictory, i. e. meaningless, signs. ${ }^{11}$ This explains why Ellul viewed propaganda as an essential element of economic technique. However, Ellul's arguments can be seen as trapped in the same circular logic as the technological society itself. While acknowledging the existence of technique as an epistemic extension of the technological imperative - or, more precisely, of the progressive ideology that underlies the Enlightenment project - he does not contradict the fact that technoscience sustains people's lives in the most straightforward sense, and that propaganda is embedded into socialization.

In this section, Ellul's linkage of propaganda with the processes of creation or exploitation of shared culture and of indoctrination will be further explored. Drawing on the contributions of authors that shared the concern with technocratic domination and technical thinking, I will look, first, into how they analysed that integration, and secondly, into how advertising positioned itself in that system as a technocratic tool for persuasion in the economic and

\footnotetext{
${ }^{9}$ In "Scientizaton of Politics and Public Opinion" (or. 1968), Habermas mentions Ellul as reference for the critique of the technocratic model of administration (1989a, 63 n. 2). He states that "technocratic administration of industrial society would deprive any democratic decision-making process of its object" (Habermas 1989a, 68).

${ }^{10}$ As Mark Poster points out in the introduction to his edition of a selection of Baudrillard's texts, "[t]he concurrent spread of the hyperreal through the media and the collapse of liberal and Marxist politics as master narratives, deprives the rational subject of its privileged access to truth. In an important sense individuals are no longer citizens, eager to maximize their civil rights; nor proletarians, anticipating the onset of communism. They are rather consumers, and hence the prey of objects as defined by the code" $(1988,7)$. This can be equated with Baudrillard's ulterior idea of a saturation of culture by "simulations" as a cynical instrumentalization of the cultural system of references.

The goal of creating images of the good life through material goods is, in this sense, nothing short of a redefinition of cultural life, severing its ties with moral, political, or religious meaning. "[C]onsumer culture through advertising, the media, and techniques of display of goods, is able to destabilize the original notion of use or meaning of goods and attach to them new images and signs which can summon up a whole range of associated feelings and desires. The overproduction of signs and loss of referents [...] is therefore an immanent tendency within consumer culture" (Featherstone 2007, 112).
} 
political realms, a phenomenon fostered by a pervasive indoctrination system. This mythbuilding and myth-exploiting system is then related to the emergence of a globalized consumerist technocracy based on digital networks.

\subsection{Ambivalent Technology: confronting Ellul and Marcuse}

Among the Frankfurt School's theorists, it is Herbert Marcuse's concern with technology and its effects on culture, his critique of technocratic ideologies and the myths of progress that share most of the scope of Ellul's work on technology and propaganda. This subsection aims to explore some aspects of those similitudes but also major differences between them, such as are both suggested and clarified in mutual references.

Ellul made numerous references to Marcuse, most of which are critical of the German author and show a fundamental divergence over the possibility of liberation from capitalist technocracy. In The Technological Bluff (1990), a convergence between the authors surfaced, specifically around the idea of technological ambivalence, that is, the open possibilities of positive and negative uses of technology that must not be confused with any form of technological neutrality (Ellul 1990, 38, 76). In The New Demons, Ellul again criticizes Marcuse for idealizing technology by investing it with the power to realize "egalitarian and democratic" goals once its "minor defects" have been corrected $(1975,115)$. This reference is, in fact, a critique of technological utopianism, especially when it is transformed into the optimistic outlook of its realization through democratic appropriation. Ellul sees this project as vague and poorly explained, degenerating on further "mythical thinking" $(1975,116)$. In the book The Ethics of Freedom, the French philosopher highlights the self-reinforcing, "selfevident" beliefs that, stemming from technological complexity, impinge upon the human making it "a creature of external determination" (Ellul 1976b, 42). In the same passage, a footnote dismisses Marcuse's analysis of the alienation problem without further comment (Ellul 1976b, n. 10). In both cases Ellul criticized Marcuse, charging him of wishing to transform modern society while maintaining industrial technology and methodologies as if the two were independent. Ellul insisted that modern technology is at odds with any truly democratic projects and, because Marcuse did not go far enough in his critique of the technological phenomenon, he seemed to be a reformer, rather than a revolutionary. ${ }^{12}$

The Technological System is Ellul's book that has the most references to Herbert Marcuse, and is the work most critical of Marcuse, although not in a detailed way. Thus, in two notes Ellul attacks One Dimensional Man as lacking in the analysis a focus on the autonomy of the technological phenomenon, overly focusing on contingent social structures and class relations $(1980,51$, notes 5 and 6$)$. Later in the same book, in other negative comments, Marcuse is brought to task for vagueness in his approach to the relation between politics and technology (1980, 156, n. 9), and for "complicating matters uselessly without contributing anything" with psychological terminology in One-Dimensional Man (1980, 327, n. 10).

For Ellul, Marcuse's critique of capitalism also appears as still too focused on the role of the ruling classes, its appropriation of technique, and how new forms of authority might regain control of technology. Jacques Ellul was, as already noted, sceptical of the possibility of opening spaces of resistance within the sphere of technology. He ascribed propaganda an important role in the naturalization of alienation, that is, of creating internalized beliefs that prevented a real alternative from emerging. Because of that, he viewed technological appropriation and rationalization as an idealization of the democratic potential of technique. While Marcuse's "theory leads to the conclusion that the derealized dimensions of art and the imagination must now be rejoined with real life through a completely new kind of scientifictechnical theory and practice" (Feenberg 1995, 32), Ellul proposed not a synthesis of

\footnotetext{
${ }^{12}$ This conceptualization is also what led Ellul to side with Habermas in his criticism of Marcuse (1989b) as overly optimistic with regard to the malleability of the relation between human, nature and technique (Ellul 1980, 169170, n. 8). This fundamental disagreement between the authors is further explored by Langdon Winner in Autonomous Technology, in which, by analysing Lenin's technological policies, he stressed that the Ellulian idea of a loss of agency in the face of technocracy and its technological pragmatic efficiency does not depend on class power $(1978,260 \mathrm{ff})$.
} 
technology and democracy, but a reconstruction of human relations with the world that would effectively erode technocratic thinking, and thus also reduce the alienating effect of propaganda. In other words, "unlike Marcuse, we are not looking at a socialist movement or revolution in any massive form, lest, according to Ellul, we risk falling back into the technical trap, but rather a revolution of a personal form which involves personal yet concrete actions. It is a clear yet difficult task - and all the more credible, in light of the Leviathan-like system of La Technique" (Holford and Saives 2013, 14).

Even though Ellul engaged with Marcuse's work, as shown, there was not a real dialogue between the authors. Douglas Kellner states that Herbert Marcuse repudiated any similarities with "autonomous technology" theory, despite not mentioning Ellul in his writings (Kellner 1984, 266-7; 442 n. 7). Instead, Marcuse consistently emphasised emancipation through changes in the social control of industrial technology, as highlighted in his critique of Max Weber (Marcuse 1968). As his work progressed beyond One Dimensional Man, Marcuse identified the countercultural movements of the 1960s as important fractures in capitalist societies that gave reasons to be optimistic about radical social change. Marcuse's approach to the problem of technological authority and domination places the instrumental ambiguity of technology as an opportunity for social change. The French author preferred an ethically grounded resistance to the technical system, refusing to ascribe technology a neutral role in the construction of freedom, while also entertaining very low hopes for radical mass movements that might reverse technical totality.

In Alternative Modernity, Andrew Feenberg agrees that Herbert Marcuse "proposed the reconstruction of the technical base of society" $(2010,200)$. Feenberg states that "in drawing us into its orbit the system has exposed itself to new forms of resistance", which demand the exploration of possibilities for political and individual action $(1995,2)$. In fact, the periodical emergence of alternative movements, and the liberating potential often assigned to new widespread technologies - particularly as the reach and scope of communication technologies has expanded in the last century - disprove the idea of a totalizing, closed society. In a sense, individuals and societies are permanently experimenting with sociotechnical arrangements that are not necessarily circumscribed by the technological system. Those ruptures offer - often missed - opportunities for reconstruction or change around shared social and cultural purposes that are disregarded in instrumental approaches to social relations.

\subsection{The Propaganda Technocracy}

Ellul places high relevance not only on social agency (technicians, capitalists, state), but also on the way the efficiency principle is widespread throughout organizations and social groups. This approach presents several important aspects that highlight its relevance. Firstly, Ellul avoids an elite theory underpinning by positing a dialectic process between social needs and elite intervention. While top-down propaganda constitutes a powerful force, horizontal or "social" propaganda, socialization and shared culture also embody persuasion systems. Dismissing these factors is to ignore Ellul's decades-long questioning of the conditions that promoted this way of thinking to its current place. In the context of his view of technique, social and individual agencies are mutually constraining, but in an asymmetrical way.

Second and related to the first reason, stating the power conditions and the network of elites is not sufficient, critically speaking, to explain the effectiveness of propaganda as technique. The interplay between ideology and praxis, between material and psychological needs, contributes to define the form of propaganda and the path of the technological society - technology is not the determinant factor. The very interdependence woven into the social system by the enabling character of technique makes it extremely hard to develop a practical philosophy that remains coherent both with humanistic morals and the fatalism of theoretical self-consciousness. As such, it is necessary to identify the motors of that interest (in Jowett and O'Donnell's terminology, "institutions" and "propaganda agents"). For Ellul, "[p]ropaganda is effective not when based on an individual prejudice, but when based on a collective center of interest, shared by the crowds" (Ellul 1973b, 49). 
A third reason is that Jacques Ellul emphasises the blurring of boundaries between economic, technological and political systems in the contemporary world, following with an appeal to shake off the thrall of the technological myths. ${ }^{13}$ As to the question of how it arose to its current position, however, Ellul attributed less importance to a major factor that was addressed by Marcuse and other critical theorists, namely the maintenance of capitalistic social relations and tensions with the transition to modern technology. As noted, Marcuse avoided an unimodal analysis (such as Heidegger's or Ellul's substantive view of technology), bringing to bear class relations, as well as the historical development of the capitalist modes of production as described by Marx and Weber in his work on technology (Kellner 2004, 5). That should not overshadow several points of convergence between Ellul and the work of critical theorists that often go unnoticed: the problematic emergence of the technological society in modernity (that is, a society driven by expertise, quantification and the "efficiency principle"), and the way "technique appears to be satisfying human needs and, in fact, is not doing so" (Sklair 1971, 221). Hence the importance of a philosophy of technology that is not overly focused on material technologies and also brings to bear expert processes and the ideology of technique as it permeates society: materiality is blended with social practices and analysing them as independent entities is an over-simplification. ${ }^{14}$

Modern organizations, and particularly the large subsystems of public space such as the media or the State, have established themselves firmly in the realm of technique. In that territory, they contribute to the acceleration of consumerist drives by exercising tight controls over products, their representations and, most importantly, over the disciplinary regulation of the consumer's body and life world. As Z. Bauman notes, "it is a condition of consumerism that the body is trained into a capacity to will and absorb more marketable goods, and that routines are instilled, through a self-inflicted drill" $(1983,41)$.

Packard was one of the first professionals to expose the interlinking of advertising culture with the conditioning of behaviour, thought, practice and ideology at a mass scale - targeting the mass as citizens and as consumers. Its emergence occurred at a time when the expansion of consumerism and mass media pushed industries to expand their markets through the creation of needs, brands, and consumer loyalties. Vance Packard chose merchandisers (and marketers) as the object of his book The Hidden Persuaders. ${ }^{15}$ Packard's work was described as a "popular version of the Frankfurt school conspiratorial vision" (Wollaeger 2008, 11) and, indeed, it was a widely read exposé of the rise of professional promotional culture after World War II.

In his book, Packard describes how professionals made it their job to understand fundamental drives individuals themselves did not know they had, mobilizing techniques from the study of political propaganda and the psychological sciences. In short, they became exploiters of the masses' psyche. Their objectives were set by anyone with something to sell; subsequently, the plan of action was developed by technicians with the expertise to arouse the interest of the individual (as citizen and/or consumer) on any given product. By the late 1950s, persuasion techniques had already reached strategic status as indispensable tools of the industrial system. On the background of its rise to prominence was the development of several areas of psychology and their convergence into what Packard refers to as "mass psychoanalysis" (1962, p. 11). Those new techniques were drawing on the study of the human mind and culture to exploit the shared symbolic world, the 'culture codes' (Rapaille 2006), in order to mobilize them within consumer culture and mass politics. ${ }^{16}$ At the same time, the persuaders acted on a different, subliminal level of indoctrination which operated in

\footnotetext{
${ }^{13}$ Ivan Illich (1972) and E. F. Schumacher (1973) also emphasize the need to expose the utopian promises of the technological will as a complex of cultural effects.

${ }^{14}$ This is what Wanda Orlikowski designated as "constitutive entanglement," a dynamic "sociomaterial assemblage" that provides a better object for studying technological practices (Orlikowski 2007, 1445).

${ }_{15}$ Packard's book was first published in 1957, only three years after Ellul originally published La Technique ou l'Enjeu du Siècle (The Technological Society).

${ }^{16}$ For example, the "selling" of a president needs to include a perspective on his personality invoking a father figure. No political candidate can forego extreme care, both with speech and physical appearance.
} 
formal and informal education, preparing the individual for a life of immersion in consumerism and efficient production.

For Vance Packard, persuasion was not limited to one aspect of everyday life. In his view, it aimed to create a form of 'groupthink' that eliminated the individual as autonomous subject. In politics, as in commercial advertising, massification and the global reach of electronic media gave rise to different kinds of persuasive techniques, tailored for democratic societies and influenced by "Pavlov and his conditioned reflexes, Freud and his father images, Riesman and his concept of modern American voters as spectator-consumers of politics and Batten, Barton, Durstine and Osborn and their mass merchandising lore" (Packard 1962, 149-150).

Vance Packard presented modern humans as being at risk of being defined, or manipulated, by a trend towards "other-mindedness, group living, and consumptionmindedness" $(1962,192)$. This re-engineering would take place through the preparation of citizens, consumers and workers by the institutions of the industrial society. Behavioural studies generated the data that would later be used to adapt institutional architectures, in order to foster compliance and consent with ideological programs, usually under the guise of economic trends and planning. This transformation can indeed be best described as the institutional homogenization of the social body according to the industrial methods developed during the early $20^{\text {th }}$ century.

Packard's book overstated the impact of propaganda and its scientific foundations, much like early media theories. In fact, Packard popularized the instrumentalist and substantive views on propaganda that dated back to the period between wars. What makes Packard still relevant is the way his discourse lingers on in popular views of propaganda as a basically top-down phenomenon, product of the machinations of expert technocracy. This view cannot be indefinitely sustained: without Ellul's important qualifications of the needs and character of propaganda, it devolves into the mystification of technical efficiency we are trying to avoid. In spite of its shortcomings, the book is mentioned by Marcuse (in the Introduction to The OneDimensional Man, p. xlix) and Ellul $(1975,70,146)$ as an important step towards awareness in its own time (the book was first published in 1957). Ellul agreed that the symbolic world of modern man - immersed in mass communication, social and horizontal propaganda - lends itself to instrumental uses. But he also warned that "[a]dvertisers do not manufacture the symbols" (Ellul 1975, 70). They select them for the reactions they can provoke and their potential to elicit action and change, as was made clear in Marcuse's analysis of the scope and aims of Nazi propaganda.

\subsection{Hidden Persuasion and Indoctrination}

Nowhere is this systemic need for indoctrination more noticeable than in the persuasion industry. In the $20^{\text {th }}$ century, especially after World War II, production capacity outstripped demand and economic resources, threatening to cause a new economic crisis. Part of the solution was to flood the public symbolic space with representations of a good life represented by readily available mass-produced goods. According to Ellul, in order to be successful, this process required a previous work of indoctrination, that is, a sensitising to those representations of life in the modern world that produces a form of alienation.

Ellul remarked that this sensitization had religious echoes. He considered that symbolism and its exploitation by advertising draws on the mechanisms of religious thinking, turning it into the "orphic delirium of consumption" (Ellul 1975, 146) through the "will to believe" in the strong, simple messages of technological myth (Ellul 1973b, 40). ${ }^{17}$ This indoctrination in the sacred powers of technology to free humanity and empower the individual towards a suprahuman condition is transparent in popular culture.

But the individual is born in an alienating environment. Ivan Illich draws on Jacques Ellul as he underlines that pervasive mobilization and its long-term manipulative effects in Deschooling Society. In the wake of Ellul, Ivan Illich was one of the most powerful critiques of

17 That aspect contradicted theories of media effects, which relied on behavioural models, and finds echoes in Baudrillard's work on simulation and Debord's thoughts on the spectacle. 
the pervasiveness of industrial rationalism in institutional practices: school, hospital, etc. His work provides an alternative view which follows Ellul's view of the role of individual moral autonomy.

Illich points out some misunderstandings in the integrationist or progressive discourse that regards ICT (information and communication technology) as part of a desirable and constant technological progress. Information technology, the myth goes, would restore citizens' control of the production and consumption cycle, relieving the masses of some of their cognitive burden. At the same time, the penetration of ICT in the scientific and social milieus would accelerate organizational, managerial, and epistemic processes, broadening the realm of technology into the foundations of matter and information. ${ }^{18}$

Although information technology could be materialized as "convivial tools" (Illich 1973, $65),{ }^{19}$ they are integral to the hegemonic industrial system. As such, ICT are charged by what Illich claimed to be a loss or degrading change in community language, linked to the role of media as vehicles of transmission of mass messages spread by centralized structures even in the case of the purportedly decentralized new media. The concept of "conviviality" is central to understanding alternative forms of production and consumption, but it is not a strictly economic concept. Its critical dimension implies social and cultural aspects:

I choose the term "conviviality" to designate the opposite of industrial productivity. I intend it to mean autonomous and creative intercourse among persons, and the intercourse of persons with their environment; and this in contrast with the conditioned response of persons to the demands made upon them by others, and by a man-made environment. I consider conviviality to be individual freedom realized in personal interdependence and, as such, an intrinsic ethical value (Illich 1973, 11, emphasis added).

This implies that the limits to the convivial potential of new technologies reside in the current economic structure or, more generally, in the technological system. The author reproaches the efficiency principle and technical rationalization adopted by modern organizations in similar terms as Ellul and Marcuse. The main concern is the closing of the horizon for action. For example, the aims of the "hidden curriculum" in education and learning are to maximize the efficiency of human resources in order to provide the industrial structure with all the means necessary for their maintenance and expansion (Illich 1972, 106). This standard is deployed as an institutionalization of efficiency values, for which the school system (a rather revealing expression) becomes a hegemonic instrument: "[a] society committed to the institutionalization of values identifies the production of goods and services with the demand for such. (...) School is the advertising agency which makes you believe that you need the society as it is" (Illich 1972, 163).

As Adorno and Horkheimer explained in The Concept of Enlightenment, "Enlightenment's program was the disenchantment of the world. It wanted to dispel myths, to overthrow fantasy with knowledge" (Horkheimer and Adorno 2002, 1). Some of the shortcomings of the Aufklärung project stem from the inability, or impossibility, to eradicate the instrumentalization of mythical thinking in legitimation by infusing the education and political systems with critical rationality. Instead, education came to be perceived as one more source of domination: "[t]he most effective propaganda combines entertainment, education and persuasion. The entertainment elements attract the audience, while the educational aspect decreases the perception that the message is propaganda, even as it persuades"

\footnotetext{
${ }^{18}$ Within this framework, emerging technologies (including ICT, nanotechnology, biotechnology, cognitive science and technology) are not truly revolutionary, but a continuation of progressively sophisticated industrial methods (Alves 2013).

${ }^{19}$ According to Illich's Tools for Conviviality "[c]onvivial tools are those which give each person who uses them the greatest opportunity to enrich the environment with the fruits of his or her vision. Industrial tools deny this possibility to those who use them and they allow their designers to determine the meaning and expectations of others. Most tools today cannot be used in a convivial fashion" (Illich 1973, 22, emphasis added).
} 
(Macdonald 2006, 32). As conveyors of symbolic and cultural representations, the media and the school system instil the values that circulate in the sociocultural environment and shape the individual's double role of citizen as consumer by conditioning responses at a social scale (eliciting a "general attitude"), that is, through the "elimination of individualizing factors" (Ellul 1973b:302). In brief, Illich, Ellul and critical theorists converged in considering that the individual was diminished, and her capacity for critique and self-reflection discouraged throughout her institutional path in centralized organizations. Additionally, this process is selfreinforcing, in that it continually creates new needs and new dependencies.

\subsection{The Protean Citizen / Consumer}

For Vance Packard, this submissive adaptation, created by a system of influence and persuasion deeply ingrained in governments and industry already in the 1950s, had the explicit purpose of "[m]oulding 'team players' for free enterprise" (Packard 1962, 165). The American writer contrasted the new value given to an "orwellian groupthink" (idem) over the traditional brand of individualism. He also established a distinction between two sorts of manipulation. The first aimed "to achieve the constructive purpose of making employees happier and more effective at their jobs" by offering them symbolic (status-related) rewards (Packard 1962, 171). The second kind of manipulation used psychological techniques and tests to "assess and remould management men" (Packard 1962, 175), which included intelligence and psycho-technical tests as well as attitudes toward authority, dignity, and family life. Every single assessment was carried out against a background of corporate interests (profit, efficiency, flexibility, loyalty) and other systemic values, such as patriotism.

As we have seen, the introduction of the industrial mode of production is not an isolated event, but rather a planned, ordered, restructuring of cultural and organizational values. What is at stake is the end of autonomy, replaced by heteronomic values. Modernization processes have a broad impact, relying on propaganda and consumption, centralization of power, and organization, all determined to a varying extent by the technological form. The institutionalization of daily practices leads to a blurring of the public sphere and citizenship, giving rise to an increasing dependence on the "industrial" system.

Each new crisis, be it economic or political, is brought up against this background of technical demands placed upon the individual. Consumerism itself is never called into question, except insofar as it can be subject to a new discipline dictated by technique. Recent examples from Southern Europe show how the financial crisis was used to put on hold even procedural notions of democratic participation, prioritizing the technical-minded readjustment of society to the demands of the globalized economy (reminding us again of Ellul's remark about the "anti-democratic economy"). Disciplined consumption is the indispensable base of economic growth, to be stimulated when it slows down too much, and regulated when it threatens macroeconomic balances. Citizenship is important only as the source of legitimation of political options - in political discourse, "citizen" is often equated with "taxpayer," signalling an economic criterion of exclusion from the political sphere.

In fact, according to Zygmunt Bauman, the inevitability of exclusion of all who lack the resources to participate in the consumption economy - the jobless, the debtors, or the "new poor" - is inherent to reduction of the human life world to the quantifiable, tradable, and profitable (2007). For all intents and purposes, the non-consumer is part of an "underclass" of "fallen consumers" that have no access to the good life of accelerating consumption and, therefore, are placed in the symbolic territory of the non-citizen (Bauman 2007, 32).

Illich believed that one of the solutions to the serious problems and inequalities in our societies rests on the re-establishing of "natural scales and limits" (Illich 1973, xii), to remedy the imbalances evident in industrialized societies and returning them to a "multidimensional balance of human life" (Illich 1973, xi). He concludes that civil society is in danger of disappearing with the extension of institutionalization. The persistence of the expansion of the production and consumption cycle as measure of quality of life raises increasing doubts about the sustainability of the global consumer society, as resource scarcity strains the ability to develop new technological solutions. 
For Ellul, this is the most salient problem with the alliance between technique and the symbolic world that propaganda represents: it locks human beings in a cycle of social and psychological dependence from the totalizing system that engulfs modern existence. The denial of possible alternatives is the main target of Ellul's outrage against consumer capitalism, and the propagandistic apparatus of economic technique. Ellul was by no means alone in perceiving the encroachment of economics in the political sphere, nor in decrying the limiting of freedom through this colonization of the public sphere. More recently, Daniel Miller highlighted the consequences of that process: the past political divisions between left and right, once united by the rejection of consumption as "political activity," have been superseded by an unquestioned compliance with economic models where the management of consumer activity (including consumer groups) plays an important role, that is, "modern politics has become a mere dependant of modern economics" (Miller 1995, 2).

This systemic perspective on propaganda, technology and consumption incorporates important observations on the organization of modern societies. Firstly, it integrates propaganda and consumption as factors in the economic system, showing how they participate in the promotion of efficiency in all sectors of society. Secondly, it shows how the technological and economic systems appropriate the symbolic world and, through socialization, refashion it into a flexible control mechanism. Thirdly, it highlights the dependency of the economic and political systems on the communication structure of modern societies.

\section{Retracing Propaganda in the Information Age: The Example of Security and Cyber Politics}

As the history of propaganda shows, it is not just amusement - entertainment, infotainment, leisure - that provides a path for propaganda and persuasion in favour of technology. While it is true that the culture industry ensures symbolic production and its circulation to and from the masses, there remains a more acute factor in what may be called the system of public opinion in the information age. It concerns the control of the infrastructure, along with the content, of information exchanges. This section is an overview of the current ideologicallyladen framing of arguments for stronger securitization of cyberspace, i. e., for more state and corporate control over the global digital telecommunication infrastructure and contents. It intends to reflect upon the colonization of cyberspace as an instance of the extensional logic of technical thinking, control and domination, and how propaganda helps that process by mobilizing myths congregating both individual and social needs.

Considering the importance of information management in the administration of means towards economic ends, questions arise concerning information networks and its role in our globalized economies. How will technological politics shape the development of digital networks? Will their democratic potential be emphasised? Or will they be regulated as commercial territories? Both as economic and communicational milieu, digital networks have risen into prominence, first as the locus of a new myth, promising the utopia of generalized connectivity and concord, then as the hyped realm of economic opportunities (ravaged by financial cycles of bursting bubbles), and now as a de-territorialized space of conflict. Digital networks, and especially the Internet, embody the strife, signalled by Ellul and Illich, between a civic symbolic sphere and techno-economic imperatives. As seen above, Ellul highlighted a dialectical construction of propaganda and social myth. He considered that the technological society was founded upon the efficiency principle and its extension to all areas of human existence. That hegemonic character depended on acceptance, compliance and adaptation - the purposes of propaganda. Ellul also pointed out, as critical theorists, that systematic propaganda was a response to the complexity of the modern world. However, as Herman and Chomsky discussed, it reinforces the current status quo and power relations and, in itself, reveals the links between economic power, politics, and importance of shaping public opinion. Illich added a stronger emphasis on indoctrination and adaptation to what he termed "industrial methodologies" which, in his view, were in the process of being augmented by a "computerized Leviathan" $(1974,5)$, that is, information technologies. 
Disasters and risks are effective catalysts for mobilization. The sense of urgency in a time of crisis is a powerful tool for behavioural conditioning, and it has been "engineered" several times in the history of propaganda. Hearst used his media empire to build up to the SpanishAmerican War. The Lusitania incident, the Pearl Harbor and 9/11 attacks, among many others, produced effects that were amplified by mass media, transformed into rallying words for the intensification of conflicts in and out of battlefields. One of the most important aspects of politics in our time is the use of disasters as catalysts for propaganda. Either real technological catastrophes, natural and humanitarian disasters, wars - or in the form of moral panics, they are purposefully used as occasions for intensifying efforts for behavioural change. Naomi Klein presented this phenomenon as the doctrine of disaster capitalism, or "shock doctrine:" an acceleration of political, social and economic programmes in the wake of natural, man-made or engineered upheaval (Klein 2007). In the same way, 'digital disaster propaganda' (under the guise of warnings of a 'digital Pearl Harbor') for example, helps the extension of technical rationalism and consumerism, as well as the spread of centralized control over digital networks. It presents cybersecurity as social need, a field where only a technical apparatus can succeed in restoring stability. The promises of a democratic cyberspace (or of cyberspace as tool for democracy) have been overshadowed by the promises of technique as security. While information technologies have been hailed for its emancipatory and decentralizing potential, new risks and threats developed new challenges to the online ecosystem. Today, responses to these threats have reframed the status of the digital sphere as a locus of conflict, the more extreme form of which - the development of cyber warfare capabilities - can be seen as a military colonization of cyberspace.

\subsection{Dystopia and Myths: Virtual Enemies and Cyber Warfare}

During the Cold War, the possibility of destruction of the military chain of command established the need to create a resilient network to decentralize communication structures. After a golden era of unfettered expansion, the Internet is now reverting to the normative structuring of a controlled space, albeit commercial instead of military. As information and communication technologies developed and converged onto digital networks, its strategic character re-emerged in a bifurcated pattern.

On the one hand, there is a persistent belief in the political potential of network technologies, which maintains that they have a liberating and individuating potential which will ensure a "democratic rationalization" (Bakardjieva and Feenberg 2002) and allow the emergence of a generalized, communitarian critical stance towards technology. This view adopts the idea of the emergence of spaces of openness with the technological system and dominant propaganda. If those spaces can be used to promote a new form of social construction, it would also be possible to revert some of the negative effects of technology and propaganda.

On the other hand, networks themselves became a matter of political and economic strife, where numerous institutional, communitarian and other more or less anarchic groups vie for control. The Internet and the networked environments it sustains - government, military, business, entertainment, news, social networking services - have entered diplomacy and the political spotlight as a new sort of battlefield. This view suggests that it is an area to be regulated and securitized in order to isolate and eliminate threats to economically vital information exchanges, as highlighted by the US Secretary of State:

Governments and citizens must have confidence that the networks at the core of their national security and economic prosperity are safe and resilient. Now this is about more than petty hackers who deface websites. Our ability to bank online, use electronic commerce, and safeguard billions of dollars in intellectual property are all at stake if we cannot rely on the security of our information networks (Clinton 2010).

By reducing Internet freedom to commercial activity, entertainment and opposing it to terrorism, censorship, espionage and organized crime, institutional actors are, once again, 
establishing a frontier. This is a propagandistic move that normalizes certain uses of technology and hyperbolically defines threats to 'condoned' activities. In other words, this kind of discourse frames Internet freedom within what Herman and Chomsky have defined as "faith in the market," thereby creating rules within which 'the market' can operate with minimal disruption. But this form of Internet freedom discourse also creates an enemy, or "faces of evil:" hackers, cyberspies, whistleblowers. By reducing dissent to criminal activity, espionage, and sabotage, it fits squarely into a form of propaganda that exalts the economic or even emancipatory potential of the Internet, while also defining patterns of acceptable uses and behaviour.

The mythical envelopment of new information technologies has undergone a multidirectional, chaotic growth that asserted the networks' roles as catalysts and databases, supported to the point of near-ubiquity by myriad devices. To posit any hard ethical stance in such a dynamic technological environment leads to reductionist dead ends, not least because of the entanglement of world-views that coexist on the Internet (Mosco 1998). The networked utopia of communication has been replaced by another myth: that of the Internet as battlefield. The time for peaceful coexistence of conflicting perspectives, if there ever was one, seems to be over. In sum, this new discourse aims to establish a deterritorialized nonborder of nation-states bent on economic mobilization to maintain geopolitical leadership. Of course, this also includes using the network as an agent of adaptation, or as a conduit thereof. Power shifts are played out as virtual warfare, either as diplomacy, or in new forms of low-intensity conflicts over intellectual property and disruptions of organizational processes.

Jeffrey Carr defines cyber-warfare as "the art and science of fighting without fighting; of defeating an opponent without spilling their blood" $(2009,2)$, an aim as ancient as war itself. Paraphrasing C. H. Gray, Neal Curtis states that "there are three central elements to cyber warfare. The first is the belief that it can be managed scientifically; the second is the belief that war is a matter of information and interpretation; the third is the emphasis on computers as the means by which the first and the second elements will be achieved" (Curtis 2006, 139, emphasis added). These elements are part of a theorization of postmodern war as a new technological myth of sanitized conflict. The inherent uncertainties of war are presented as minimized, first, through a phenomenological conversion of the physicality of the battlefield into massive informational pools, and, second, through a migration of high-intensity conflict into cyberspace, under the guise of propagandistic actions, industrial espionage and information controls.

These are signs of trouble for the network variety of techno-utopians. A 2011 OECD report stated that current doctrines, terminologies and policies are responding to a hyperbolic sense of urgency that does not correspond to a real systemic risk (Sommer and Brown 2011, 5-8). The authors stress the need to look beyond fears and propaganda (that is, perceived threats and risks) in order to understand the extent to which institutional actors need to implement cyber-security measures. In fact, governments and international organisms are increasingly worried about network safety. The President of the United States of America has unveiled various plans for national and international cyberspace strategies (The White House 2009; 2011; The White House and National Security Council 2011), in the wake of several civilian and military initiatives aimed to increase readiness against threats of cyber-attacks on infrastructure, services, institutions and companies - themselves being met by diplomatic actions since 2009. Besides this new cyber war political positioning, there are also signs of the preparation of complete strategic and tactical frameworks by the United States' Department of Defense and the North Atlantic Treaty Organization.

As the Internet is transformed into the locus of sabotage, propaganda and a permanent struggle for valuable information, the outlook becomes less favourable to the democratization in online governance. These developments signal a new stage of maturity of the virtual world - namely, its colonization by nation-states. On one hand, it is a normative colonization: it presents a view of cyberspace and a set of sanctioned (shopping, commercial entertainment, news, business) uses vis-à-vis a number of undesirable or 'unsafe' uses (file sharing, political activism, information disclosure). On the other hand, it has a strong military component. This 
effort is a complement to the geostrategic positioning of state and non-state actors that have taken the initiative. In brief, it reveals a willingness to exploit the generalized connectivity of globalized societies (Payne 2009, 110-111).

The development of cyber warfare and digital espionage capabilities represents additional dimensions of the current creation of a heavily controlled cyberspace. The drive for the development of cyber-weapons came from the perceived need to defend strategic assets and to protect freedom in the online environment, while also using that medium to spread information and collect intelligence ${ }^{20}$ Meanwhile, the hopes for a cosmopolitan technology a self-organized, self-regulated, and commercialized Internet - were definitely exposed as the re-enactment of similar, earlier myths related to other communication technologies (Latouche 2006).

\subsection{Myths of Progress and Innovation as Systems of Propaganda}

A social myth is a powerful image. It describes the aspirations and values of a social group, creating a norm, objectives, or guidelines for action. It also integrates a given set of representations which are widely circulated and used within that social group. As O'Shaughnessy defined,

A myth may be described as a story or event that illuminates the key values of some society or association: the events can be real or imaginary, but, almost certainly, imagination will have embroidered them. The propagandist, thus, draws from the existing stock of social mythologies as well as adding to them (O'Shaughnessy 2004, 88).

Propaganda is central to this new sphere of spectacular simulations. The myths of alterity and difference compound the technological myths, themselves a combination of higher-order representations of wealth and power through material progress. Insofar as digital communication technologies partake in both these fields, they also become vulnerable to instrumentalization and propaganda efforts.

The most powerful myth of the modern age presents history as a linear process of amelioration in the conditions of the existence of humankind. Science and technology are seen as the driving forces of the betterment of the human condition. Industrial methods, themselves related to historicist ideologies of progress, exacerbate the risks of the extension of a single method to all areas of human activity in a process of generalized rationalization. According to Illich (and Ellul, as previously stated), the institutions of the nation-state were inspired by the industry and its methods: education, health, army, transportation and communications follow the organizational paradigm of the factory and perpetuate its methodologies (Illich 1972).

For Ellul, technique as a system depends on the ability to accelerate and streamline information exchanges. In fact, planning and forecasting have become increasingly harder (Ellul 2004, 298ff). As new technological forms emerge, and with them more sophisticated products and methods to master, adapting the existing structures is more than a competitiveness problem: it is a matter of systemic continuity. ICT, in particular, are put in place as a synthesis of technique, reunifying the plurality of elements and functions of the technological systems already in place. The general drives for automation, of efficient production, alongside the increased efficiency in distribution, marketing, and organization, underline the importance of the management of abundance through information processing an idea encapsulated in Henri Lefebvre's expression "bureaucratic society of managed consumption" (Lefebvre 1996, 147). Ivan Illich referred to the resulting system as the "computerized Leviathan" $(1974,5)$. Propaganda, as part of the technological system, has taken the task of adapting societies to this new paradigm, "seducing" and "tempting" (Van der Laan 2004) individuals with the power of disembodied access.

\footnotetext{
${ }^{20}$ An example of which is the Stuxnet worm, which allegedly played a part in bringing Iran's nuclear program to a temporary standstill by disabling an important part of its machinery.
} 
At the local and global level, information can cross the globe instantly through direct reports and second-hand repetitions. The importance of this flow cannot be overstated: transparency in political and economic matters is a pillar of democracy and should be central to a society that values citizenship (Schudson 2008). The quality of individual participation in public affairs depends on an ethical, active stance towards all dimensions of life. Mass and digital media can contribute to either foster or impair transparent practices (they are characteristically ambivalent, as propaganda studies have shown). Some of the limits to the perceived emancipatory potential of digital networks stem from the interventions of nationstates in the cyber sphere, precisely in the form of security initiatives (the latest examples coming, in 2013, from the revelations about widespread electronic surveillance). The promotion of digital democracy and global online commerce notwithstanding, it is possible that the denial of resources or the surveillance of political action in cyberspace plays an important role in those interventions.

In order to overcome Ellul's admonition and to be in accordance with the stated principles of democracy, an informed citizen would need to access accurate, relevant information. Ideally, this need would be answered by efficient communication systems, populated by professional and technicians that produce and relay that information. However, the international, relatively centralized, property structure of mass media and their large financial stakes, make them reluctant to take the risks that inhere in being the counter-power unravelling propaganda's systematic, instrumental approach to the symbolic sphere. On the contrary, the permanent search for new ways to attract audiences is at odds with such task. For this reason, digital communication networks may have introduced some degree of counter-balancing democracy. But, as noted, a backlash against the open possibilities of digital communication has been forming, as cyberwarfare, new regulations and pervasive surveillance transform the ideological landscape by way of appeals to security, control and limits to access. This has highlighted the susceptibility of the digital ecosystem to the effects of direct and indirect propaganda, as well as of direct intervention, and suggests that Ellul's critical outlook of the possibilities of emancipation within the technological realm is accurate.

Democracy and consumption are part of the ideological structure of the new cyber-utopia. "Contemporary propaganda implies that technological improvements within information society will ultimately lead to the arrival of the perfect state in which all desires of consumers will be fulfilled" (Karim 2001, 118). Not only does that discourse depend on a difficult to prove correlation between democracy and information, but it also invokes the allure of the Edenic myth of painless progress towards wealth and well-being. Investing ICT with the garments of emancipation is equivalent to the deliberate production of a strategic economic asset which is also the locus of a morally charged claim of participatory citizenship. The underlying praxis requires individuals and nations to enter a kind of hermeneutic relationship with technologies, though opposed to the humanistic enlightenment which Ellul advocated. The goal would be the creation of a code to allow the actualisation of the promise of technique, both in the producer's life and in society as a whole. Here, innovation is rhetorically construed as the path to utopia because of its hypothetical potential to mobilise individuals and groups for the task of closing the gap between the political, economic and technical systems. Something that Ellul and Illich rejected as a mirage ascribable to functional distortions of the organic, evolving macro-system of technique, as already noted.

\section{Conclusion}

The framework of propaganda studies has not lost its relevance. Although communication studies have paid less attention to propaganda analysis after the end of the Cold War and as scientific theories favoured effects and uses of media and technologies, a new look might be in order. In fact, the early mythologizing of new media, which focused on discontinuities, has not yet given way to an inquiry into the continuities of its symbolic role in the communication sphere. New media seem to be fertile ground to exacerbated hopes for democracy and participation, but also a potent vehicle for propaganda messages. Digital communication networks are often credited with changing the paradigm for communication, but more effort 
needs to be made towards a convergence of approaches in order to analyse comparatively, as well as historically, the messages and ideological content of the encompassing articulation of technique and culture.

Ellul's contribution to propaganda studies may now be appreciated in a different light. Other propaganda definitions fail to account for the effectiveness of social myths, mainly by assuming a vertical, top-down structure of message dissemination with high impact, while overlooking horizontal and social propaganda. In fact, mass media are not the sole driving force, although it is impossible to deny their crucial role in the professionalization of propaganda. The Herman and Chomsky propaganda model accounts for the logic of privatization that forces a closing of public communication around capitalist elites. There is no reason to believe it is not applicable to the transition to online media (which shifted financing flows to targeted advertising and e-business in general, but maintained the economic links between media and corporation).

Another important aspect of technological transition is the logic of extension of the propaganda and technical systems. According to the Frankfurt School theorists, this configuration was an all-encompassing system that assimilated its counterparts while "working around" its contradictions through innovation and the mobilization towards consumption, against a background of glorification of technical progress. This 'methodology', when applied to current trends in information politics, translates into a normative colonization that established a hegemonic myth for cyberspace: an insecure sphere that needs to be controlled and treated as a territory of struggle in order to avoid chaos and unpredictability.

Ellul's horizon - as a philosopher, social thinker and a Christian believer - was to highlight individual moral autonomy. Technique invites the individual, as citizen and consumer, to accompany its myths of progress and technological bliss by submitting to the principle of efficiency. Propaganda plays a major role in that mobilization. However, even as it helps making sense of the modern world, it places human beings in the position of dependency that further reduces the individual's autonomy. If modernization requires such a degree of conformity and standardization, then the role of propaganda is to keep dissent, nonconformity or alternatives at a minimum, and in the most marginal position possible in all social arenas. It is, in fact, a matter of conserving and concentrating social resources within the logic of technique.

The transition from traditional to modern societies has been, mainly, the result of technical amendments to nature, opening up possibilities for action over the natural and the social worlds. Its implementation, however, created social and political problems. Even when used to carry out identical or similar tasks, propaganda actions, resource exploitation, automation, and technical bias in education amplify, instead of merely replacing, social and cultural gaps, thereby countering the very existential practices and conditions of human autonomy that made their emergence possible after the Enlightenment. Technique does not make distinctions between means and ends, nature and society. In fact, it connects them tightly, and in no point in history more evidently so than after information technology accelerated the unification of the technical system.

Propaganda and mythologies of the connected self and society have reached an unparalleled intensity. This has led to a hyped discourse that pays little heed to the concerned arguments this paper analyses. Recent developments - such as the consecutive cyber-attacks on companies and governments, the WikiLeaks cases and corporate reaction, the actions of the hacker group Anonymous, the race for Internet kill switches - have shown that the virtual world built over our informational infra-structure is not exempt from controls and limitations. The Internet is as much a disputed economic asset as a vehicle for symbolic exchanges. It is a medium (or several media tied together), but also a disembodied territory of strife and domination. In that sense, it is a perfect metaphor for an age when identity and sociability are turned into the hidden objects of persuasion.

Jacques Ellul believed that the desire for efficiency and positivistic scientific credibility gave rise to new elites, different from the engaged public intellectuals of the humanist liberal arts tradition, and more committed to private gain. The media and learning institutions that 
shouldered the responsibility of safeguarding the human spirit against its instrumentalization, have fallen prey to the technological system's catering to ambition.

As I tried to show, Jacques Ellul's arguments have not lost validity. As Marcuse's, Ellul's work poses a daunting question: why should technology, an integral part of being human and living in the world, be reduced to an aggressive, destructive force, an end unto itself? Why should technological fixes take the place of rational debate over the fundamental goals of human life and the ways to pursue it? For the citizen, a lightning rod for influence and persuasion, it is increasingly clear that most roles, in the private and public spheres, have been constrained into strict consumer models. Democratic representation underpinned by technique as administrative and control tools shows evident signs of capture by commercial and military interests, with too little accountability. Overlooking the modern societal need for propaganda and wishing for a reversal of its pervasiveness are not viable options. Instead, the sources and purposes of propaganda can be addressed from critical and moral standpoints as promoting instrumentalization and domination, and exposed as such. As the previous analysis made clear, Ellul is sceptical regarding the possibility of overcoming technocratic propaganda, due to its central role in the fulfilment of technological instrumentality and efficiency.

A degree of disentanglement from the monism of technique - the coupling of technocracy and propaganda, in this case - can be achieved if the individual is conscious of his exposure to persuasion techniques and acts to counter them. Alternative progressive emancipatory politics can counteract propaganda and serve social needs instead of imposing the heteronomous goals of exploitative technocratic systems upon society. To extricate oneself from the propaganda system is a critical, reflexive undertaking: it requires acknowledging the role of propaganda, understanding how it operates through shared culture and symbols (including education systems and socialization), and unveiling the purposes of the propagandist.

This reflexive individualistic focus, evocative of the anti-propaganda education of the interwar period, is very strong in Ellul. However, it would give only a small hope for an alternative since it relies on personal enlightenment, suggesting an ethical awakening, rather than critical political action. A society without propaganda being impossible to achieve, especially if we take into account the link between social needs and the purpose of propaganda, Ellul's hope resides in the possibility of transformative action, enacted in constructive relationships with others in everyday life - collective action grounded in individual responsibility and reflexive autonomy.

This would open additional methods to design a progressive social program of disentanglement that subverts the capture of public communication. To emancipate a group from propaganda would require a convivial reworking of identity, that is, a form of socialization based on new relationships. This 'counter-ideal', that is, the confluence of autonomous individuals sharing a non-instrumental approach to social relations and communication, would demand not only pluralistic communication channels permeating society, including the online channels currently under siege, but also a reversal of the 'human techniques' that produce and manage the modern individual as consumer and disciplined citizen. Thoroughly pluralistic economic and political systems can only emerge when centralized forms of technocratic governance have been not only deconstructed, but replaced at the societal level.

Jacques Ellul's work remains relevant, but unfinished. Almost a century of technology and communication studies, and an era of prosperity for developed countries, were largely framed by advances in science and technology. However, it is debatable whether the political sphere has survived the onslaught of specialization, or if it has, as the French philosopher feared, morphed into a dramatized simulation of discursive practices where only the myth of public deliberation and participation remains. In sum, between the technological system and democracy, the former has taken the lead, and the need for a critical disentanglement of the two has never been greater. 


\section{References}

Alves, Artur Matos. 2013. Criador e Criatura: Informação e Comunicação no Contexto das Tecnologias Emergentes. Lisbon: Fundação Calouste Gulbenkian / Fundação para a Ciência e Tecnologia.

Bakardjieva, Maria, and Andrew Feenberg. 2002. Community Technology and Democratic Rationalization. The Information Society: An International Journal 18 (3): 181-92. doi:10.1080/01972240290074940.

Baudrillard, Jean. 1978. Le Système des Objets. Paris: Gallimard.

Baudrillard, Jean. 1988. Selected Writings. Ed Mark Poster. Stanford: Stanford University Press.

Baudrillard, Jean. 1996. La Société de Consommation. Paris: Gallimard.

Bauman, Zygmunt. 1983. Industrialism, Consumerism and Power. Theory, Culture \& Society 1 (3): 32-43. doi:10.1177/026327648300100304.

Bauman, Zygmunt. 2007. Collateral Casualties of Consumerism. Journal of Consumer Culture 7 (1) (January 3): 25-56. doi:10.1177/1469540507073507.

Bernays, Edward. 1928. Propaganda. New York: Horace Liveright.

Black, Jay. 2001. Semantics and Ethics of Propaganda. Journal of Mass Media Ethics 16 (2): 121137.

Carr, Jeffrey. 2009. Inside Cyber Warfare: Mapping the Cyber Underworld. Sebastopol, CA: O'Reilly Media.

Christians, Clifford G. 1995. Propaganda and the Technological System. In Public Opinion and the Communication of Consent, ed Theodore L. Glasser and Charles T. Salmon, 156-174. New York / London: The Guilford Press.

Clinton, Hillary Rodham. 2010. Remarks on Internet Freedom. U. S. Department of State - Diplomacy in Action. Accessed December 2, 2012. http://www.state.gov/secretary/rm/2010/01/135519.htm.

Curnalia, Rebecca M. L. 2005. A Retrospective on Early Studies of Propaganda and Suggestions for Reviving the Paradigm. Review of Communication 5 (4): 237-57. doi:10.1080/15358590500420621.

Curtis, Neal. 2006. War and Social Theory: World, Value and Identity. Basingstoke / New York: Palgrave Macmillan.

Ellul, Jacques. 1962. Propagandes. Paris: Librairie Armand Colin.

Ellul, Jacques. 1973a. The Technological Society. New York: Vintage Books/Random House.

Ellul, Jacques. 1973b. Propaganda: The Formation of Men's Attitudes. New York: Vintage Books/Random House.

Ellul, Jacques. 1975. The New Demons. New York: The Seabury Press.

Ellul, Jacques. 1976a. Histoire de la Propagande. 2nd ed. Paris: Presses Universitaires de France.

Ellul, Jacques. 1976b. The Ethics of Freedom. Grand Rapids: W. B. Eerdmans.

Ellul, Jacques. 1980. The Technological System. New York: Continuum.

Ellul, Jacques. 1990. The Technological Bluff. Grand Rapids: W.B. Eerdmans.

Ellul, Jacques. 2004 [1977]. Le Système Technicien. Paris: le cherche midi.

Ellul, Jacques. 2010. Responsabilités de la Propagande. Topique 111 (2): 7-15. doi:10.3917/top.111.0007.

Featherstone, Mike. 2007. Consumer Culture and Postmodernism. Thousand Oaks: Sage Publications Limited.

Feenberg, Andrew. 1995. Alternative Modernity: The Technical Turn in Philosophy and Social Theory. Berkeley: University of California Press.

Feenberg, Andrew. 2010. Between Reason and Experience: Essays in Technology and Modernity. Cambridge MA: The MIT Press.

Fischer-Kowalski, Marina, and Helmut Haberl. 1997. Tons, joules, and Money: Modes of Production and their Sustainability Problems. Society \& Natural Resources: An International Journal 10 (1): 61-85. doi:10.1080/08941929709381009.

Habermas, Jürgen. 1962. The Structural Transformation of the Public Sphere. Cambridge: Polity Press.

Habermas, Jürgen. 1989a. The Scientization of Politics and Public Opinion. In Toward a Rational Society, 62-80. Cambridge: Polity Press. 
Habermas, Jürgen. 1989b. "Technology and Science as 'Ideology." In Toward a Rational Society, 81122. Cambridge: Polity Press.

Herman, Edward S. 1996. The Propaganda Model Revisited. Monthly Review 48: 115-128.

Herman, Edward S. 2000.The Propaganda Model: A Retrospective. Journalism Studies 1 (1): 101112.

Herman, Edward S., and Noam Chomsky. 2002 (1988). Manufacturing Consent: The Political Economy of the Mass Media. New York: Pantheon Books.

Herman, Edward S., Noam Chomsky, and Andrew Mullen. 2009. The Propaganda Model after 20 Years: Interview with Edward S. Herman and Noam Chomsky. Westminster Papers in Communication and Culture 6 (2): 12-22.

Holford, W. David, and Anne-Laure Saives. 2013. "The Future (and the Now) according to Jacques Ellul: Deterministic or Mindful?” Futures 47 (March): 9-16. doi:10.1016/j.futures.2012.11.003.

Horkheimer, Max, and Theodor W. Adorno. 2002 (1944). Dialectic of Enlightenment: Philosophical Fragments. Stanford: Stanford University Press.

Horkheimer, Max. 2004 (1947). Eclipse of Reason. London / New York: Continuum.

Illich, Ivan. 1972. Deschooling Society. New York: Harper \& Row.

Illich, Ivan. 1973. Tools for Conviviality. New York: Harper \& Row.

Illich, Ivan. 1974. Energy and Equity. New York: Harper \& Row.

Jerónimo, Helena M., José L. Garcia, and Carl Mitcham, ed. 2013. Jacques Ellul and the Technological Society in the 21st Century. Philosophy of Engineering and Technology. Dordrecht: Springer.

Jowett, Garth S. 1987. Propaganda and Communication: The Re-emergence of a Research Tradition. Journal of Communication 37 (1): 97-114. doi:10.1111/j.1460-2466.1987.tb00971.x.

Jowett, Garth S., and Victoria O'Donnell. 2012. Propaganda and Persuasion. 5th ed. Thousand Oaks: Sage Publications.

Karim, Karim H. 2001. Cyber-Utopia and the Myth of Paradise: Using Jacques Ellul's Work on Propaganda to Analyse Information Society Rhetoric. Information, Communication \& Society 4 (1): 113-134.

Kellner, Douglas. 1984. Herbert Marcuse and the Crisis of Marxism. Berkeley: University of California Press.

Kellner, Douglas. 2004. Introduction: Radical Politics, Marcuse and the New Left. In The New Left and the 1960s: Collected Papers of Herbert Marcuse, 1-37. London: Routledge.

Klaehn, Jeffery. 2009. The Propaganda Model: Theoretical and Methodological Considerations. Westminster Papers in Communication and Culture 6 (2): 43-58.

Klein, Naomi. 2007. The Shock Doctrine: The Rise of Disaster Capitalism. New York: Metropolitan Books.

Krausmann, Fridolin, Marina Fischer-Kowalski, Heinz Schandl, and Nina Eisenmenger. 2008. The Global Sociometabolic Transition. Journal of Industrial Ecology 12 (5-6): 637-656.

Van der Laan, James M. 2004. Temptation and Seduction in the Technological Milieu. Bulletin of Science, Technology \& Society 24 (6): 509 -514. doi:10.1177/0270467604270258.

Latouche, Serge. 2006. Les illusions de la techno-démocratie de marché mondialisée. Revue européenne des sciences sociales (XLIV-134). Quel(s) défi(s) pour les sciences sociales à l'heure de la mondialisation ? (June 1): 181-192.

Lefebvre, Henri. 1996. Writings on Cities. Oxford: Blackwell.

Macdonald, Scot. 2006. Propaganda and Information Warfare in the Twenty-First Century (Contemporary Security Studies): Altered Images and Deception Operations. 1st ed. London / New York: Routledge.

Marcuse, Herbert. 1964. One-Dimensional Man: Studies in the Ideology of Advanced Industrial Society. Boston: Beacon Press.

Marcuse, Herbert. 1968. Industrialization and Capitalism in the Work of Max Weber. Negations 208: 201-226.

Marcuse, Herbert. 2004. Technology, War and Fascism: Collected Papers of Herbert Marcuse. London: Routledge.

Merrin, William. 2008. "After the End": Baudrillard's Future. French Cultural Studies 19 (3) (October): 255-271. doi:10.1177/0957155808094939.

Miller, Daniel. 1995. Consumption as the Vanguard of History - a Polemic by Way of an Introduction. In Acknowledging Consumption - a Review of New Studies, 1-52. London / New York: Routledge. 
Mosco, Vincent. 1998. Myth-ing Links: Power and Community on the Information Highway. The Information Society: An International Journal 14 (1): 57-62. doi:10.1080/019722498129015.

Mullen, Andrew, and Jeffery Klaehn. 2010. «The Herman-Chomsky Propaganda Model: A Critical Approach to Analysing Mass Media Behaviour». Sociology Compass 4 (4): 215-229.

Orlikowski, Wanda J. 2007. "Sociomaterial Practices: Exploring Technology at Work." Organization Studies 28 (9): 1435-48. doi:10.1177/0170840607081138.

O'Shaughnessy, Nicholas. 2004. Persuasion, Myth and Propaganda. Journal of Political Marketing 3: 87-103. doi:10.1300/J199v03n03_05.

Packard, Vance. 1962. The Hidden Persuaders. Harmondsworth: Penguin Books.

Payne, Kenneth. 2009. Winning the Battle of Ideas: Propaganda, Ideology, and Terror. Studies in Conflict \& Terrorism 32 (2): 109-28. doi:10.1080/10576100802627738.

Porquet, Jean-Luc. 2004. Préface - Ellul l'avait bien dit. In Le Système technicien, 7-12. Paris: le cherche midi.

Poster, Mark. 1988. Introduction. In Baudrillard - Selected Writings, 1-13. Stanford: Stanford University Press.

Rapaille, Clotaire. 2006. The Culture Code: An Ingenious Way to Understand Why People Around the World Live and Buy as They Do. New York: Broadway Books.

Schudson, Michael. 2008. Why Democracies Need an Unlovable Press. Cambridge / Malden, MA: Polity Press.

Schumacher, Ernst F. 1973. Small is Beautiful: a study of economics as if people mattered. New York: Vintage.

Silva, Filipe Carreira da. 2002. Espaço Público em Habermas. Lisbon: Imprensa de Ciências Sociais.

Sklair, Leslie. 1971. The Sociology of the Opposition to Science and Technology: With Special Reference to the Work of Jacques Ellul. Comparative Studies in Society and History 13 (2): 217235.

Sommer, Peter, and lan Brown. 2011. Reducing Systemic Cybersecurity Risk. Future Global Shocks. London: OECD / IFP. Accessed December 2, 2012. http://www.oecd.org/dataoecd/57/44/46889922.pdf.

Sparks, Colin. 2007. Extending and Refining the Propaganda Model. Westminster Papers in Communication and Culture 4 (2): 68-84.

Sussman, Gerald. 2011. Introduction: The Propaganda Society. In The Propaganda Society: Promotional Culture and Politics in Global Context, 1-21. New York: Peter Lang Publishing, Incorporated.

Sussman, Gerald. 2012. Systemic Propaganda as Ideology and Productive Exchange. tripleC: Communication, Capitalism \& Critique. Open Access Journal for a Global Sustainable Information Society 10 (2): 474-487.

Taylor, Philip M. 2003. Munitions of the Mind: A History of Propaganda from the Ancient World to the Present Day. 3rd edition. Manchester: Manchester University Press.

The White House. 2009. Cyberspace Policy Review: Assuring a Trusted and Resilient Information and Communications Infrastructure. Washington, D. C.: The White House. Accessed November 15, 2012. http://www.whitehouse.gov/assets/documents/Cyberspace_Policy Review final.pdf.

The White House. 2011. International Strategy for Cyberspace: Prosperity, Security and Openness in a Networked World. Washington: The White House. Accessed November 15, 2012. http://www.whitehouse.gov/sites/default/files/rss viewer/internationalstrategy cyberspace.pdf.

The White House, and National Security Council. 2011. The Comprehensive National Cybersecurity Initiative. Accessed January 10, 2013. http://www.whitehouse.gov/cybersecurity/comprehensivenational-cybersecurity-initiative.

Winner, Langdon. 1978. Autonomous Technology: Technics-out-of-Control as a Theme in Political Thought. Cambridge MA / London: The MIT Press.

Winner, Langdon. 2013. Propaganda and Dissociation from Truth. In Jacques Ellul and the Technological Society in the 21st Century, 99-113. Philosophy of Engineering and Technology. Dordrecht: Springer.

Wollaeger, Mark. 2008. Modernism, Media, and Propaganda: British Narrative from 1900 to 1945. Princeton / Oxford: Princeton University Press. 


\section{About the Author}

Artur Matos Alves

Auxiliary Professor in the Department of Sciences and Technologies of Information and Communication of the Atlântica University, and researcher in CECL, New University of Lisbon, Portugal. His most recent book, Criador e Criatura (Calouste Gulbenkian Foundation, Portugal, 2013) reflects his PhD dissertation on emerging technologies, presented to the New University of Lisbon in 2010. He edited the book Unveiling the Posthuman. Oxford: Inter-Disciplinary Press (2012). His research on philosophy of technology and the societal impacts of emerging technologies, new media and cyber conflict has been presented in international conferences, books, and journals. 